\title{
Effects of continuous embankments and successive run-of-the-river dams on bedload transport capacities along the Rhône River, France
}

\author{
Daniel Vázquez-Tarrío ${ }^{\mathrm{a}, *}$, Michal Tal ${ }^{\mathrm{a}}$, Benoît Camenen ${ }^{\mathrm{b}}$, Hervé Piégay ${ }^{\mathrm{c}}$ \\ a Aix Marseille Univ, CNRS, IRD, INRA, Coll France, CEREGE, Aix-en-Provence, France \\ ${ }^{\mathrm{b}}$ Irstea, UR RiverLy, Centre de Lyon-Villeurbanne, 5 Rue de la Doua, CS 20244, 69625 Villeurbanne, France \\ ${ }^{c}$ University of Lyon, CNRS UMR 5600 EVS, Site ENS, Lyon, France
}

\section{A R T I C L E IN F O}

Article history:

Received 4 August 2018

Received in revised form 7 December 2018

Accepted 8 December 2018

Available online $\mathrm{xxx}$

Keywords:

Bedload

Rhône river

Dams

River embankment

Sediment transport
A B S T R A C T

This study was aimed at untangling the relative impacts of successive phases of human modifications on changes in bedload transport along a $430 \mathrm{~km}$-long river reach: the Rhône River from Motz dam to the sea. We used a 1D hydraulic model to solve for water lines across a range of discharges and all along the reach. Next, using grain sizes measured in the channel, we estimate flow competence and mean annual bedload transport capacities using the Recking (2013) bedload transport equation. In addition, we used the Generalized Threshold Model to estimate the relative fine and coarse fractions of the load. Bedload transport estimates were carried out under present-day hydraulic conditions and compared to estimates based on model runs simulating an unimpeded flow regime and using grain sizes measured in bars as a proxy for conditions prior to armouring.

Our results show that present-day bedload transport along the Rhône is significantly fragmented by multiple closely spaced dams. Mean annual bedload capacity varies between 2500 and $16,300 \mathrm{~m}^{3} /$ year over all the reaches, with an average of $4700 \mathrm{~m}^{3} /$ year. Results of the GTM analysis suggest that this load is composed of $89 \%$ fines. We find bed sediment mobility to be very low in most reaches, and that potentially mobile sediments are finer than the median grain size in the riverbed even at high flows. Our results suggest that bedload capacities were 25-35 times higher prior to bed armouring and flow modifications; dams had an impact 2-3 times more important on transport capacities than channel embankments, and bed armouring was foremost a response to channel embankments. Based on an analysis of the ratio of sediment yields to transport capacities, we propose a conceptual scheme illustrating how bedload supply, channel morphology, and surface texture coevolved in the Rhône over the past century and half.

\section{Introduction}

The effects of widespread human modifications of rivers are well documented (e.g., Tricart and Bravard, 1991; Schiemer et al., 1999; Surian, 1999; Surian and Rinaldi, 2003; Lóczy, 2007; Surian and Cisotto, 2007; Olivier et al., 2009; Hohensinner et al., 2014; Frings et al., 2014a, 2014b; Bravard and Gaydou, 2015; Arnaud et al., 2017). River embankments and bank protection are known to decrease sediment inputs from lateral erosion and reinforce sediment storage in fluvial margins (Provansal et al., 2014; Dépret et al., 2017a). Channel narrowing is also associated with suppression of alternate bars and reductions in morphological heterogeneity (e.g. Surian and Rinaldi, 2003; Bravard, 2010; Duró et al., 2015). Gravel mining can drastically modify bed topography and decrease or increase sediment storage (Petit et al., 1996; Kondolf, 1997; Brunier et al., 2014). Finally, large dams disrupt longitudinal sediment flux and modify flow regimes, thereby inducing imbalances between sediment supply and

\footnotetext{
* Corresponding author at: INDUROT, University of Oviedo, Mieres, Spain. Email address: vazqueztarrio@cerege.fr (D. Vázquez-Tarrío)
}

flow (Williams and Wolman, 1984; Kondolf, 1997; Brandt, 2000; Vörösmarty et al., 2003; Graf, 2005, 2006; Magilligan and Nislow, 2005; Petts and Gurnell, 2005; Schmidt and Wilcock, 2008; Dade et al., 2011; Kondolf et al., 2014; Camenen, 2017). Yet, despite our understanding of these processes, the task of characterising the effects of separate human modifications and isolating causal factors driving channel change present a unique challenge on rivers with long and complex histories of human development carried out in multiple phases. These rivers are likely adjusting simultaneously to changes in several control variables and were still adjusting to previous modifications when a new one began. The pre-management equilibrium condition is therefore either irrelevant or poorly constrained. This challenge is highlighted by the relatively few studies considering the effects of dams on previously altered river systems (Gölz, 1994; Frings et al., 2014a, 2014b; Siele et al., 2017; Arnaud et al., 2017).

Dams represent a major driver of channel change throughout the second half of the 20th century (Petts and Gurnell, 2005; Nilsson et al., 2005; Vericat and Batalla, 2006; Grant, 2012; Skalak et al., 2013; Provansal et al., 2014), and many large rivers contain multiple dams (e.g. Colorado River -Williams and Wolman, 1984-, Yellow River -Chien, 1985-; Piave River -Surian, 1999-, Danube River -Schiemer 
et al., 1999-; Ebro River -Vericat and Batalla, 2006-; Sacramento River -Singer, 2006-; Amazonas River -Anderson et al., 2018). A multi-dam series can have important impacts on sediment transfers and geomorphic interactions between successive reaches and may have a cumulative impact downstream. Despite the potentially far-reaching effects of dam series, most studies on the effects of dams focus on the influence of single dams and do not consider their combined effects. A study by Skalak et al. (2013) on the Upper Missouri river is the only one we are aware of that explicitly analysed the geomorphological consequences of interactions between successive dams.

An understanding of the role of individual forcings on the evolution of river systems, as well as what a given system is presently adjusting to are key issues to targeting restoration efforts and predicting river response to future anthropogenic and natural changes. This is especially relevant in light of ambitious restoration efforts underway specifically aimed at reversing or mitigating the adverse effects of human modifications described above which were widespread since the late 19th century and throughout the 20th century (Habersack and Piégay, 2007). A physically-based quantitative understanding of present-day conditions is particularly important given the shift away from restoring static fluvial forms (e.g. Schiemer et al., 1999) towards restoring sediment transport and ecological and morphodynamic processes (Stroffek et al., 1996; Dufour and Piégay, 2009; Arnaud et al., 2017) based on actions involving channel widening, riprap removal, reactivation of secondary channels, sediment replenishment below dams, and gravel augmentation (e.g. Gaeuman, 2012; Ock et al., 2013; Lamouroux et al., 2012; Arnaud et al., 2017; Dépret et al., 2017b).

The Rhône River in France constitutes the archetype of large European Rivers that owe their present-day geomorphic character to several major periods of human modifications and containing multi-dam series. It is thus well suited to a study aimed at quantifying both the impacts of changes to multiple control variables as well as interactions amongst inter-dam reaches. In this study we quantify for the first time bedload transport along the Rhône and analyse its variability through time and space. Our estimates are based on bathymetry and grain size collected and compiled through the OSR (Rhône Sediment Observatory; Parrot, 2015) and a 1D hydraulic model, also developed as part of the OSR, (Dugué et al., 2015, 2016; Launay et al., this issue) and used here for the first time in a geomorphic study. The results of this paper provide an insight into how human modifications modified the Rhône River through the continuous interactions amongst bed-evolution, transport capacities, and bed texture along different parts of the Rhône. On a broad level, this study illustrates an example and an approach for untangling the causes of channel change on large rivers subject to long histories of human regulation. The detailed results of this study are expected to help target restoration on a reach-by-reach basis on the Rhône River.

\section{Study case}

The Rhône River is one of the major European rivers and constitutes one sixth of the total runoff into the Mediterranean Sea (Fruguet and Dessaix, 2002). Its main water source is the Rhône glacier near the Furka pass in the Swiss Alps. It has a total length of $812 \mathrm{~km}$ and a drainage basin area of $98,500 \mathrm{~km}^{2}\left(90,500 \mathrm{~km}^{2}\right.$ within France). The French portion of the Rhône begins downstream of Lake Geneva and consists of $512 \mathrm{~km}$ from the Alps down to the Camargue Delta and the Mediterranean Sea (Fig. 1). The average annual discharge of the Rhône based on measurements at the Beaucaire gauging station $\sim 60 \mathrm{~km}$ from the mouth (Fig. 1) is approximately $1850 \mathrm{~m}^{3} / \mathrm{s}$ (100-year-return period flood $\sim 10,300 \mathrm{~m}^{3} / \mathrm{s}$; Provansal et al., 2014). Its highly variable basin geology (the Rhône traverses three mountain ranges - the Alps, the Jura, and the Massif Central), several major and widely differing tributaries (e.g., Ain, Saône, Isère, Ardèche, Durance), and a valley partially covered by glaciers during the last alpine glaciations (the Riss and the Würm), result in a heterogeneous system characterised by alternating reaches of hard and soft beds, incised valleys and wide floodplains, and highly distinct sediment inputs (Bravard, 2010).

The Rhône River within France underwent two major waves of human development over the last 150 years (Michelot, 1989; Cortier and Couvert, 2001; Fruguet, 2003; Parrot, 2015). The first period of major channel modifications (1860-1930) consisted of the construction of dikes and groynes (collectively known as the Casiers Girardon) designed to narrow the channel and promote incision in order to facilitate navigation. A first dam, Cusset, consisting of two canals (Jons and Miribel) was built during this first period (1894-1899) immediately upstream of Lyon. However, the major wave of hydropower management took place during the second wave of human development from 1948 to 1986 . During this second period, a series of 20 dams and 17 canals that bypassed the original channel were constructed for the production of hydro-electricity (Fig. 1). Gravel mining was widespread along the Rhône's main stem and tributaries from the 1950s through the 1990s (EGR, 2000; Cœur, 2017). Finally, sediment supplies from tributaries were strongly decreased due to sediment trapping and extractions at tributary confluences designed to prevent channel aggradation in the main stem.

The net result of these human interventions is an incised channel characterised by almost continuous embankments along its lowermost $300 \mathrm{~km}$. The dams imposed a particular planform organization on the main stem consisting of a repeated sequence of 17 bypassed channels running parallel to a diversion canal that merge into a non-regulated 'Total Rhône' channel. A diversion dam at the upstream of each sequence controls water discharge to both the diversion canal and the bypassed Rhône. The hydropower scheme's regulation rules consist of a minimum residual flow discharge delivered to the old natural bypassed Rhône during normal flow conditions and a maximum discharge diverted to the canal during floods. When river discharge exceeds the hydropower plant's capacity, sluice gates in the bottom of the dam are opened allowing excess discharge to flow into the bypassed Rhône. This opening allows some of the bed material that has accumulated upstream of the dam to be transferred as bedload to the downstream bypassed subreach.

It is commonly accepted that embankments along the Rhône River increased average bed shear stresses in a narrowed band of channel triggering channel degradation, a decrease in the availability of in-channel stocks of active gravels, and development of a coarse amour layer (Bravard, 2010; Parrot, 2015). Next, hydropower schemes strongly altered planform patterns and hydraulics in the main channel as well as disrupted longitudinal sediment transfers. This narrative constituted our working hypothesis in designing the study presented here.

\section{Methods}

This study was carried out for the Rhône River between the Motz dam and the Mediterranean Sea (Fig. 1) - a length of $430 \mathrm{~km}$ consisting of 17 run of the river dams. A reach is defined as a segment of the Rhône River between two successive diversion dams. As such, each intra-dam reach consists of a subreach of bypassed channel in its upstream half and an unregulated 'Total Rhône' subreach downstream of the confluence of the bypassed channel and the diversion canal (herein referred to as the restitution). Table 1 summarizes the 


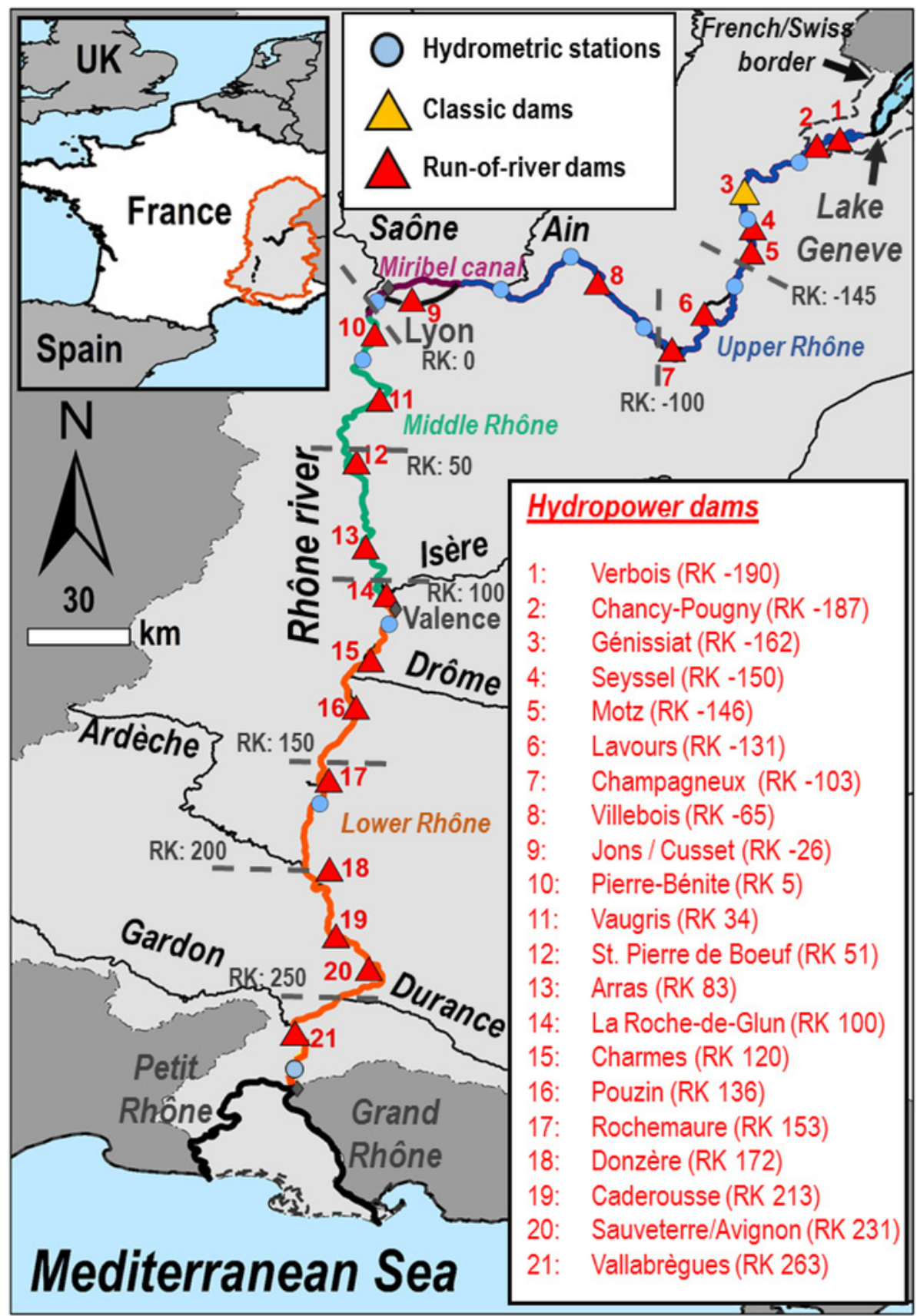

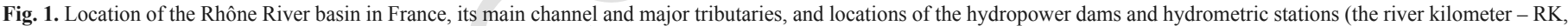
is defined as 0 in Lyon and increasing downstream, i.e. inlet from Genova lake is located at $-200 \mathrm{~km}$ and the outlet in the Mediterranean Sea at $310 \mathrm{~km}$ ).

main features of the different individual reaches along the Rhône's main channel.

\subsection{Available data}

The Rhône's prominent role in navigation and hydropower coupled with today's focus on flood management and restoration has resulted in an exceptional dataset on a large regulated river comprised of bathymetry, discharge records, and grain size distributions. This study makes use of the following existing data in the analyses presented here.

\subsection{Bathymetry}

Channel bathymetry of the Rhône river and tributaries is used in this study based on the surveys conducted by the Compagnie $\mathrm{Na}$ tionale $d u$ Rhone (CNR), the French waterway authority (VNF), and local management agencies (SYMADREM and SMAVD) between 1999 and 2008. On the Rhône's main stem, surveys were carried out along approximately 1500 cross-sections with an average spacing of $500 \mathrm{~m}$. 
Table 1

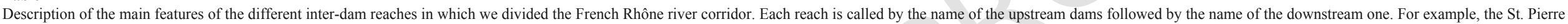
de Boeuf/Arras reach refers to the portion of Rhône main channel between the St. Pierre de Boeuf (upstream) and the Arras (downstream) dams.

\begin{tabular}{|c|c|c|c|c|c|c|c|c|c|c|c|c|c|}
\hline \multirow[t]{2}{*}{ Reach } & \multirow[t]{2}{*}{ Extent } & \multirow[t]{2}{*}{$\begin{array}{l}\text { Confluence } \\
\text { point }\end{array}$} & \multirow[t]{2}{*}{$\begin{array}{l}\text { Backwater's } \\
\text { upstream } \\
\text { boundary }\end{array}$} & \multicolumn{3}{|c|}{ Length $(\mathrm{km})$} & Slope $(\% o)$ & \multirow[b]{2}{*}{$\begin{array}{l}\text { Non- } \\
\text { regulated } \\
\text { channel }\end{array}$} & \multicolumn{2}{|c|}{$\begin{array}{l}\text { Mean annual discharge } \\
\left(\mathrm{m}^{3} / \mathrm{s}\right)\end{array}$} & \multirow[t]{2}{*}{$\begin{array}{l}\text { Residual } \\
\text { discharge } \\
\left(\mathrm{m}^{3} / \mathrm{s}\right)\end{array}$} & \multirow[t]{2}{*}{$\begin{array}{l}\text { Maximum } \\
\text { diverted } \\
\text { discharge }\left(\mathrm{m}^{3} / \mathrm{s}\right)\end{array}$} & \multirow[t]{2}{*}{$\begin{array}{l}\text { Average } \\
\mathrm{D}_{50}(\mathrm{~mm})\end{array}$} \\
\hline & & & & Reach & $\begin{array}{l}\text { Bypassed } \\
\text { channel }\end{array}$ & $\begin{array}{l}\text { Non- } \\
\text { regulated } \\
\text { channel }\end{array}$ & $\begin{array}{l}\text { Bypassed } \\
\text { channel }\end{array}$ & & $\begin{array}{l}\text { Bypassed } \\
\text { channel }\end{array}$ & $\begin{array}{l}\text { Non- } \\
\text { regulated } \\
\text { channel }\end{array}$ & & & \\
\hline Motz/Lavours & $-146 /-131.7$ & -136.7 & -140.0 & 14.3 & 9.3 & 5 & 1.1 & 0.3 & 75 & 400 & 70 & 700 & 37 \\
\hline Lavours/Champagneux & $-131.7 /-103.1$ & -114.6 & -119.0 & 28.6 & 17.1 & 11.5 & 0.8 & 0.3 & 110 & 400 & 90 & 700 & 45 \\
\hline Champagneux/Villebois & $-103.1 /-63.7$ & -91.7 & -102.9 & 39.4 & 11.4 & 28 & 0.6 & 0.2 & 150 & 440 & 65 & 700 & 28 \\
\hline Villebois/Jons & $-63.7 /-26.7$ & -61.9 & -32.0 & 37.0 & 1.8 & 35.2 & 2.5 & 0.3 & 50 & 480 & 20 & 700 & 32 \\
\hline Jons/Lyon & $-26.7 / 0$ & -9.2 & - & 26.7 & 17.5 & 9.2 & 0.6 & 0.5 & 210 & 630 & 86 & 570 & 48 \\
\hline Pierre Bénite/Vaugris & $3.8 / 33.8$ & 15.0 & 15.0 & 30.0 & 11.2 & 18.8 & 0.7 & 0.2 & 250 & 1090 & 100 & 1380 & 48 \\
\hline $\begin{array}{l}\text { Vaugris/St. Pierre de } \\
\text { Bœuf }\end{array}$ & $33.8 / 50.8$ & - & 35.0 & 17.0 & - & - & - & 0.3 & - & 1090 & - & - & 37 \\
\hline St. Pierre de Bøuf/Arras & $50.8 / 82.7$ & 63.0 & 63.0 & 31.9 & 12.2 & 19.7 & 0.6 & 0.3 & 200 & 1100 & 85 & 1600 & 44 \\
\hline Arras/La Roche de Glun & $82.7 / 99.4$ & 86.6 & 87.0 & 16.7 & 3.9 & 12.8 & 1.1 & 0.3 & 180 & 1110 & 56 & 1620 & 67 \\
\hline $\begin{array}{l}\text { La Roch de Glun/ } \\
\text { Charmes }\end{array}$ & $99.4 / 119.5$ & 108.2 & 105.0 & 20.1 & 8.8 & 11.3 & 0.3 & 0.3 & 140 & 1110 & 72 & 2000 & 26 \\
\hline Charmes/Pouzin & $119.5 / 135.7$ & 126.3 & 127.0 & 16.2 & 6.8 & 9.4 & 0.8 & 0.4 & 190 & 1470 & 72 & 2100 & 48 \\
\hline Pouzin/Rochemaure & $135.7 / 152.6$ & 143.7 & 144.0 & 16.9 & 8 & 8.9 & 0.5 & 1.0 & 230 & 1550 & 75 & 2100 & 93 \\
\hline Rochemaure/Donzère & $152.6 / 170.7$ & 165.9 & 168.0 & 18.1 & 13.3 & 4.8 & 0.8 & 0.9 & 270 & 1560 & 76 & 1850 & 84 \\
\hline Donzère/Caderousse & $170.7 / 212.8$ & 200.5 & 201.5 & 42.1 & 29.8 & 12.3 & 0.8 & 0.2 & 270 & 1560 & 75 & 1980 & 56 \\
\hline Caderousse/Sauveterre & $212.8 / 230.1$ & 218.3 & 216.5 & 17.3 & 5.5 & 11.8 & 0.9 & 0.2 & 260 & 1660 & 78 & 2280 & 65 \\
\hline Sauveterre/Vallabrègues & $230.1 / 262.4$ & 243.8 & 232.0 & 32.3 & 13.7 & 18.6 & 0.3 & 0.4 & 700 & 1700 & 400 & - & 24 \\
\hline Vallabrègues/Diffluence & $262.4 / 279.3$ & 269.1 & - & 16.9 & 6.7 & 10.2 & 0.4 & 0.1 & 340 & 1780 & 84 & 2200 & 46 \\
\hline
\end{tabular}




\subsection{Grain size}

Grain sizes along the bed of the Rhône were sampled as part of a large-scale field campaign carried out by the OSR in collaboration with the CNR between 2014 and 2015. Details of the methods and data are presented in Parrot (2015). Surface samples of the channel bed were collected approximately every $5 \mathrm{~km}$ along the length of the bypassed and Total Rhône reaches. In addition, surface and subsurface samples were collected from sporadic gravel bars.

\subsection{Flow discharge and water levels}

The CNR and the Regional Environment Planning and Housing Agency (DREAL) operate 10 gauging stations along the main stem of the Rhône as well as along all the major tributaries. Flow discharges and water levels from these stations are available through the French Hydrological Database (BanqueHydro).

\subsection{Water surface slope}

Present-day water surface slopes at low flow were obtained from the BDT-Rhône data base (IGN). These data were used to identify the extent of the backwater zone upstream of each dam.

\subsection{D hydraulic model}

This study uses an existing 1D hydrodynamic model of the French Rhône based on the numerical software MAGE developed at Irstea Lyon (Faure, 2009; http://www.irstea.fr/mage). For details regarding model development, validation, and calibration readers should refer to Dugué et al. $(2015,2016)$. No additional model development was carried out as part of this study and as such only a brief summary is provided here.

The model is based on CNR bathymetric data (details above) for the period between 1999 and 2008. The MAGE software simulates open-channel flows in transient regimes by solving the 1D Barré-de-Saint-Venant (shallow water) equations using a four-point finite difference scheme (Preissmann scheme). Non-linearities are solved using a quasi-Newton iteration (Faure, 2009). Network topology of the numerical model is loop-meshed (bifurcation, confluences), allowing to account for islands and multiple downstream boundary conditions concerning node's geometry. The model can account for compound channel effects by using the Debord formula (Nicollet and Uan, 1979; Dugué et al., 2015). The downstream boundary conditions of the model are water levels measured at Grand-Boisviel and Petite-Abbaye for the 'Grand' and 'Petit' Rhône branches respectively within the delta. Bathymetry of the major tribu- taries (Arve, Ain, Saône, Isère, and Durance Rivers), between their confluence with the Rhône to the nearest hydrometric station upstream, are included in the model. All other tributaries are represented as local inputs.

The model incorporates the hydropower schemes for all dam operations on the river based on two regulation rules: a fixed maximum water level in the reservoir as a function of discharge, and discharge partitioning between the bypassed subreach and the diversion canal during floods (Dugué et al., 2015). The model was calibrated and validated for each reach for a wide range of discharges from low water to flood conditions using water long profiles based on measurements by the CNR at several hydrometric stations (Dugué et al., 2015).

\subsection{General workflow}

Fig. 2 summarizes the steps of the workflow that were carried out for this study. First, a synthetic flow duration curve was constructed from available discharge data (see above) for the entire length of the Rhône River (within France) and adjusted to account for tributary inputs. In order to produce a continuous curve along the whole length, we assigned increases in discharge between two successive hydrometric stations to water inputs from the tributaries located between these stations based on the calculation of the weighted contribution of each tributary to the average annual discharge in the reach.

From the synthetic flow duration curve, we generated a discharge time-series (hydrogram) corresponding to the upstream-most node of the model as well as each tributary represented in the model. These hydrograms defined the boundary conditions. Each hydrogram was composed of a series of discharges between low flow and the 10-year-return period flood. This approach allowed us to estimate the hydraulic conditions for each reach corresponding to the same flow occurrence probability. Model outputs included water surface elevation, stream velocity, water depth, wetted width, perimeter, and area. These results were used to estimate the energy slope $S_{f}$ using the Manning's formula:

$$
S_{f}=\frac{U \cdot K_{s}}{R^{\frac{2}{3}}}
$$

where $R$ is the hydraulic radius and $K_{s}$ the Strickler coefficient. The Strickler coefficient value for which the 1D model was calibrated and validated was used in this study (it includes all dissipation terms).

Bed shear stresses were estimated based on the Du Boys (1879) 'hydraulic radius-water slope' product:

$$
\tau_{a v}=\rho \cdot g \cdot S_{f} R
$$

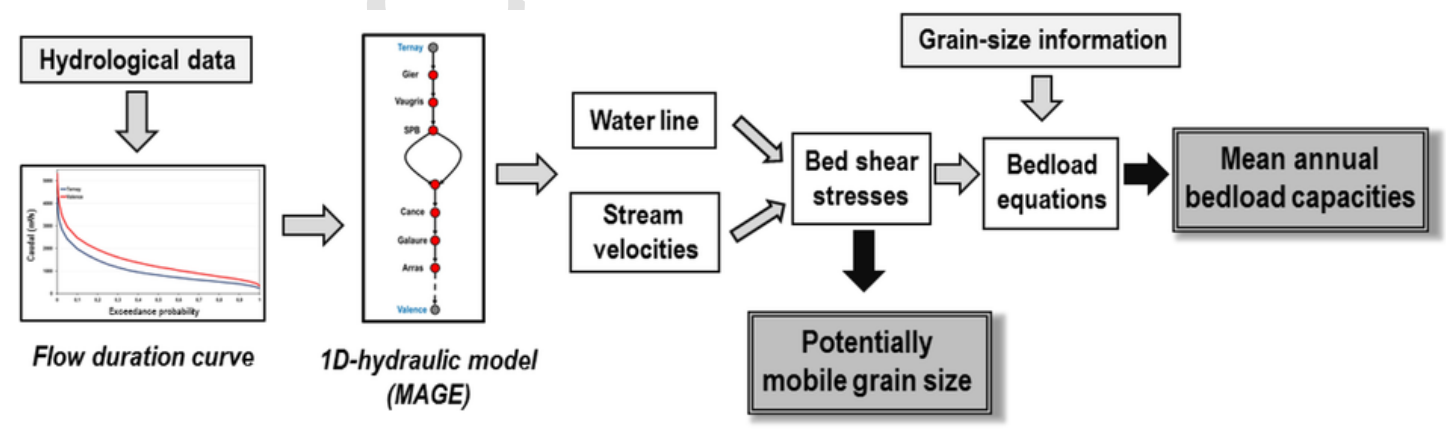

Fig. 2. Workflow used in this study to characterise the hydro-sedimentary regime along the Rhône river. 


$$
\tau_{\max }=\rho \cdot g \cdot S_{f} \cdot d_{\max }
$$

where $\tau_{a v}$ is the section-averaged bed shear-stress, $\tau_{\max }$ is the maximum local bed shear stress in the cross-section, $g$ is the gravity acceleration, $\rho$ is the water density and $d_{\max }$ the maximum water depth. In addition, we used the Meyer Peter and Müller (1948) correction to determine the effective bed shear stress $\tau_{\text {eff }}$ acting on grain particles:

$$
\tau_{\text {eff }}=\left(\frac{K_{s} \cdot D_{90}^{\frac{1}{6}}}{26}\right)^{\frac{3}{2}} \cdot \tau
$$

where $D_{90}$ is the 90th percentile of the grain size distribution (GSD).

Eventually, effective shear stresses were used to characterise flow competence (potential mobile grain size) for different discharges based on the classical relationship:

$$
D_{m o b}=\frac{\tau_{e f f}}{\left(\rho_{s}-\rho\right) \cdot g \cdot \theta}
$$

where $D_{m o b}$ is the potential mobile size, $\rho_{s}$ the sediment density $\left(2650 \mathrm{~kg} / \mathrm{m}^{3}\right)$, and $\theta$ the threshold Shield's criterion for incipient motion for which we used a value of 0.03 (Parker et al., 2003).

In this contribution, we assumed that hydropower plants always operate at maximum capacity as it is usually the case for flood frequency lower than the 1 in 10 year flood (Le Coz, com. pers.). Our flow simulations represent a worst-case scenario in flow reductions in the bypassed-subreaches for the simulated highest flows in cases hydropower plant do not operate at maximum capacity.

\subsection{Bedload transport capacities}

Estimated effective bed shear stresses were introduced into bedload formulae to compute bedload transport capacities at each of the modeled cross-sections. Grain sizes (see Section 3.1 above - available data) were linearly interpolated between samples $(\sim 100)$ to estimate grain sizes for all modeled transects $(\sim 900)$.

In order to determine which bedload transport equation was best adapted for the Rhône River, we compared four equations well suited to gravel-bed rivers with the same range of slopes as observed in the Rhône River (approximately 0.001-0.1; Pitlick et al., 2009; Vázquez-Tarrío and Menéndez-Duarte, 2015; Recking et al., 2016) to a sediment budget conducted from high-resolution morphological evolution analysis (Dépret et al., this issue). The four equations we tested were the Meyer Peter and Müller (1948; after Wong and Parker, 2006), Wilcock and Crowe (2003), Camenen and Larson (2005), and Recking (2013; after Recking et al., 2016) formulae, herein referred to as MPM, WC, CL and R, respectively. The analyses were performed on data from the Arras/La Roche-de-Glun reach (RK 90-100) based on bathymetry (27 transects spaced $100 \mathrm{~m}$ apart) and mean daily discharge between 1999 and 2004 (Dépret et al., this issue). Bathymetric measurements consisted of $1-4 \mathrm{pts} / \mathrm{m}^{2}$ with a vertical precision of \pm 10 to $20 \mathrm{~cm}$. This reach, comprised of the La-Roche-de-Glun dam and reservoir, was the subject of such a detailed study owing to nine sand augmentation campaigns from 1997 to 2014. The study by Dépret et al. (this issue) confirmed that the reach underwent important morphological changes over this period: a sediment budget conducted from morphological evolution estimated $13,600 \mathrm{~m}^{3}$ of net erosion.

Total bedload transported at each cross-section was estimated using each of the four equations. The bed elevation change volume $\Delta V$ for each sub-reach was estimated as the sum in volume change between each consecutive pair of cross-sections:

$$
\Delta V=\sum\left(Q_{S_{\text {out }}}-Q_{S_{\text {in }}}\right) \cdot(1-p)
$$

where $Q_{\text {Sout }}$ and $Q_{\text {Sin }}$ are the volumes of bedload estimated from the equations for the downstream and upstream cross-sections respectively and $p$ is the average porosity of bed material. A global bed material budget for the reach was based on the sum of volumetric changes calculated between each pair of cross-sections to be compared to the measured volumetric change equal to $27,800 \mathrm{~m}^{3}\left(20,700 \mathrm{~m}^{3}\right.$ erosion, $7100 \mathrm{~m}^{3}$ deposition). MPM and CL provide estimates of total changes below those observed (12,150 and $5560 \mathrm{~m}^{3}$ respectively). WC and R gave comparable results approximately $50 \%$ above values obtained from the sediment budget $\left(45,500 \mathrm{~m}^{3}\right.$ and $41,200 \mathrm{~m}^{3}$ of total volume changes respectively). Given the intrinsic variability in bedload transport (Gomez et al., 1989; Recking et al., 2012; Bergillos et al., 2016), all four equations performed correctly (less than one order of magnitude difference) compared to the estimate based on morphological evolution. Since estimates were slightly closer using the R formula, we proceeded to use this equation to estimate bedload transport along the Rhône River.

We assume that uncertainties linked to hydraulic computations (slope, water depth) remain negligible compared to uncertainties linked to estimates of surface grain size. As such, we attribute uncertainties in transport estimates at each cross-section solely to uncertainties in grain size. Uncertainties in transport estimates were computed as the product of an estimate of grain size uncertainty and the first-derivative of the transport function with respect to grain size (McLean, 1985):

$$
\Delta_{q}^{*}=\Delta D \cdot \frac{\partial f\left(D, S_{f}, R\right)}{\partial D}
$$

where $\Delta q^{*}$ is the uncertainty in bed load transport, $f(D)$ is the bedload function, and $\Delta D$ is the uncertainty in grain-size at a given cross-section:

$$
\Delta D=\sigma_{D}^{2}+\sigma_{\text {int }}^{2}
$$

We considered uncertainties in grain size to derive from two sources of error. The first was the representability of sediment samples: we estimated the standard deviation $\left(\sigma_{D}\right)$ in grain-size estimates based on three samples collected at each sample site to be on average $11 \mathrm{~mm}$ for the entire Rhône River. The second was uncertainties associated with our assumption that grain-size distribution at unsampled sites is accurately estimated through linear interpolation between the nearest samples upstream and downstream of a given cross-section. They were evaluated from the standard deviation of grain size errors, i.e., we estimated the difference between all measured grain size and equivalent estimates using linear interpolation and obtained a standard deviation $\left(\sigma_{\text {int }}\right)$ of $39 \mathrm{~mm}$. 


\subsection{Bedload transport capacities by size fraction}

In addition to estimating bulk volume of bed load transported along the Rhône River, we were interested in determining how total mass was distributed between fine sediments (sand to fine gravel) and coarse sediments (medium gravel to cobble). To accomplish this, we used the 'Generalized Threshold Model' (GTM) proposed by Recking (2016). The model enables computation of the GSD of bedload based on knowledge of the surface GSD and bed shear stress at each cross-section. The model is carried out in two steps. First, maximum transportable grain size is computed from an 'inverted' version of a hiding function:

$$
M=84 \cdot\left(\frac{\tau_{84}^{*}}{\tau_{c 84}^{*}}\right)^{\beta}
$$

where $M$ is the bed surface percentile corresponding to the largest size transported for a given boundary shear stress, and $\tau^{*}{ }_{84}$ and $\tau^{*}{ }_{c 84}$ are the Shields parameter computed for the 84th percentile of the grain-size distribution and its critical value for onset of motion, respectively (Recking, 2013).

Next, the percentages of mobile particles in each size range are computed from:

$$
\begin{aligned}
& \varphi_{i}=0.001+\left(1-\left(\frac{i}{M}\right)^{\gamma}\right) \\
& \gamma=0.1+0.5 \cdot\left(\frac{\tau_{84}^{*}}{\tau_{c 84}^{*}}\right)^{\gamma_{2}}
\end{aligned}
$$

where $\varphi_{i}$ denotes the fraction of the $i$ th bed surface percentile that is mobile for a given bed shear stress. Based on the estimation of $\varphi_{i}$, the fraction $F_{i}$ of bed load material in the $i$ th grain size range is estimated from:

$$
F_{i}=\frac{\varphi_{i}}{\sum_{i=1}^{M} \varphi_{j}}
$$

Finally, volumes of the bulk bedload $\left(V_{b u l k}\right)$ into the ith grain size range $\left(V_{i}\right)$ are estimated:

$$
V_{i}=F_{i} \cdot V_{b u l k}
$$

Two parameters in the GTM model, $\beta$ and $\gamma_{2}$, are unknown a priori and need to be site-calibrated from field data. Fortunately for our analysis, some data on incipient motion were available from past field experiments conducted by the CNR using tagged stones at two sites near the city of Lyon (Fig. 1): Pierre-Benite/Vaugris reach (Ramette and Heuzel, 1962) and Jons/Lyon reach (Miribel canal) (Poinsart, 1992; Petit et al., 1996). Ramette and Heuzel (1962) reported on a tracer experiment in the Rhône River below its confluence with the Saône River, in which pebbles $(25 \mathrm{~mm}-75 \mathrm{~mm})$ were tagged with radioactive tantalum. They described partial transport and provided estimates of shear stresses based on their observations of four transport episodes. Poinsart (1992) and Petit et al.
(1996) carried out an experiment using painted pebbles ( $5 \mathrm{~mm}-300 \mathrm{~mm})$ in the Miribel canal (Jons/Lyon reach) and compared their observations from two floods with estimates of shear stresses. Table in Appendix A summarizes the results compiled from both experiments. We used the data from radioactive sediment tags (Ramette and Heuzel, 1962) at Pierre-Benite and from painted stones at Miribel (Petit et al., 1996) to calibrate the beta-parameter of Eq. (8) (Fig. 3A). We obtained an optimum $\beta$-parameter of 1.3. We used the data from Poinsart (1992) and Petit et al. (1996) to calibrate the $\gamma_{2}$-parameter in Eq. (10) (Fig. 3B): a $\gamma_{2}$-parameter equal to 20 optimizes the estimation of median grain size. Both values are comparable to those found by Recking (2016) using the Oak Creek data, $\left(\beta=2, \gamma_{2} \sim 20\right)$. Next, we applied the calibrated GTM to our hydraulic model outputs to estimate the average GSD of bedload carried by the Rhône.

\subsection{Evaluation of anthropogenic modifications on bedload transport capacities}

In order to assess the influence of flow regulation on bedload transport capacities in the bypassed subreaches, we modified the regulation rules of the hydraulic model so that water flowed naturally through the bypassed subreaches, thus simulating an unimpeded flow regime. Next, we repeated the workflow outlined in Section 3.2 in order to estimate bedload capacities for the non-regulated hydrologic regime. We estimated the effects of backwater due to dams on bedload transfers by comparing estimates of bed shear stresses associated with pre-dam and post-dam water slopes for a 2-year, 5-year and 10-year discharge. According to Recking's (2013) formula, bedload
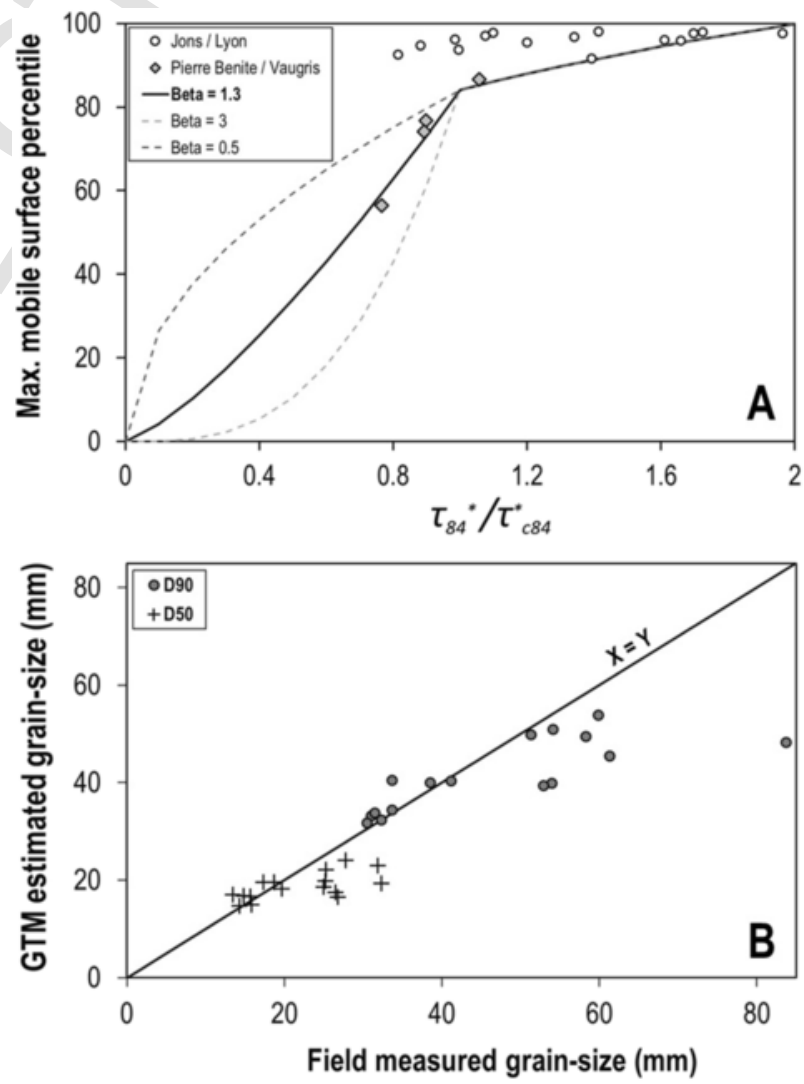

Fig. 3. Results of the GTM model (Recking, 2016) calibration for the Rhône river based on data from Poinsart (1992) and Petit et al. (1996) for the Miribel canal. A) Calibration of the $\beta$-parameter in Eq. (8); B) calibration of the $\gamma_{2}$ parameter in Eq. (10) 
transport rates are linked to bed shear stresses as follows:

$$
q^{*} \propto 14 \cdot\left(\frac{\tau_{84}^{*}}{\tau_{m}^{*}}\right)^{6.5} \quad q^{*}=\frac{q_{s v}}{\left(\rho_{s}-\rho\right) \cdot g \cdot D_{84}^{3}}
$$

where $q_{s v}$ is volumetric bedload rate per unit-width and $\rho_{s}$ the sediment density. Consequently, changes in bedload transport rates $\left(\Delta q_{s}\right)$ due to backwater effects can be estimated by the following ratio:

$$
\Delta q_{s}=\frac{q_{\text {final }}^{*}}{q_{\text {beginning }}^{*}} \propto\left(\frac{\tau_{84 \text { final }}^{*}}{\tau_{84 \text { beginning }}^{*}}\right)^{6.5}
$$

Next, we estimated the effects of sediment deficits associated with dams, tributaries, and widespread incision triggered by river embankment, and subsequent bed armouring on bedload transport capacities in the Rhône River. Our approach was based on the fact that the GSD of bars, particularly subsurface grain size, constitutes a robust proxy for the grain size of bedload supplied to the channel as well as the GSD of the average annual bedload (Kuhnle and Willis, 1992; Lisle, 1995; Church and Hassan, 2005; Segura and Pitlick, 2015; Venditti et al., 2017). We therefore considered the GSD of surface and subsurface samples collected on gravel bars (see details above in Section 3.1) to represent the conditions before channel incision, armour development and the loss of active gravels on the Rhône. Relatively few data exist insofar as bars are scarce along the main stem Rhône following the significant and widespread channel incision and degradation that occurred over the twentieth century (Parrot, 2015). We compared bedload transport computations for all the reaches in which grain size information was available for the channel and the surface and subsurface of bars. Based on the bedload computations using different GSDs, we estimated the ratio $R_{\text {qsa }}$ :

$$
R_{q s a}=\frac{q_{s_{-} \text {surface }}}{q_{\text {s_subsurface }}}
$$

where $q_{s, \text { surface }}$ and $q_{s, \text { subsurface }}$ are sediment discharge estimates based on the GSD of the armour layer and subsurface layer, respectively. According to Dietrich et al. (1989), this ratio serves as a metric of the sediment supplied into a system. According to several authors (e.g. Dietrich et al., 1989; Venditti et al., 2017), surface grain size should adjust to variations in this 'bedload supply ratio'.

\section{Results}

\subsection{Influence of dams on flow regime and hydraulics}

Data summarized in Table 2 make clear that flow regulation significantly impacts the hydrology of the bypassed subreaches of the Rhône. Residual discharge in these subreaches is typically between 10 and $30 \%$ of mean annual discharge upstream of the preceding dam. In addition, flow regulation led to an important reduction in frequency of high discharges: average number of days per year with discharges close to annual flows $\left(1000-2000 \mathrm{~m}^{3} / \mathrm{s}\right)$ in the bypassed channels decreased from approximately 40-130 days/year to approximately 1-10 days/year. Reductions in peak flows were also significant: peak discharges during 2-year, 10-year and 50-year flows in the bypassed channel are on average $48 \%, 62 \%$ and $69 \%$ of peak flows under a natural hydrologic regime, respectively (Table 2).
Given how discharge is partitioned in the model (discussed above), estimated reductions in peak flows and flood frequency represent the maximum possible reductions.

Reductions in peak flows were not, however, uniform across all reaches. In the case of the Vaugris/St. Pierre-de-Boeuf reach, which does not consist of a derivation canal, peak flows remained the same following dam construction. Meanwhile, the Jons/Lyon reach (Miribel canal) and Sauveterre/Vallabrègues reach represent two end-member cases of modified regimes: peak discharges in the Jons/Lyon reach were only weakly disturbed, representing $70-80 \%$ of natural peak discharges. In contrast, peak discharges in the Sauveterre/Vallabrègues reach were reduced to approximately $10 \%$ of pre-regulation values. Additionally, peak flows in the French Upper Rhône are more affected by flow regulation linked to dams than the middle or lower parts of the Rhône (Table 2).

Hydraulic model outputs underscore how strongly present-day hydraulics of the Rhône River are compartmentalised by dams (Fig. 4). Water lines show significant decreases upstream of each dam due to backwater effects. These backwater effects persist to some degree even during high flows (e.g., 10-, 20-, 50-year-return periods). On average, present-day water slopes upstream of dams are $34 \%$ and $48 \%$ of pre-dam slopes for 2-year and 10-year flows, respectively (Table 2). On average, two thirds of the length of reaches are within the backwater of the downstream dam (although variability exists amongst reaches). In many cases, the upstream limit of the backwater zone is roughly the confluence between the diversion canal and the bypassed channels (Pierre Bénite/Vaugris, St. Pierre-de-Boeuf/Arras, Arras/La-Roche-de-Glun, La-Roche-de-Glun/Charmes, Pouzin/ Rochemaure, Donzère/Cadereousse reaches), while in others, backwater propagates upstream into the bypassed subreach (Motz/Lavours, Lavours/Champagneux, Champagneux/Villebois, La-Roche-de-Glun/ Charmes, Caderousse/Sauveterre and Sauveterre/Vallabrègues). Finally, three reaches are almost entirely influenced by backwater (Champagneux/Villebois, Sauveterre/Vallabrègues, Vaugris/St. Pierre-de-Boeuf reaches) while in two cases backwater effects propagate only a short distance upstream (Rochemaure/Donzère, Villebois/ Jons reaches).

\subsection{Flow competence and present-day bedload transport capacities}

The results of our analysis show important differences in Shields values amongst reaches of the Rhône River (Fig. 5). In the upstream reaches (upstream of the confluence with the Ain River), the average Shields parameter for a 2-year flow remains below the critical value for bed sediment entrainment assumed equal to 0.03 (Parker et al., 2003; Parker, 2004). Meanwhile, downstream of the confluence with the Ain (Villebois/Jons, Miribel canal), the critical Shields parameter is typically exceeded during floods. The Shields parameters are again below 0.03 downstream of Lyon, with values for a 2 -year flood around $40 \%-65 \%$ of its critical value. Our comparison of bed shear stresses associated with pre-dam and post-dam water slopes points towards an average 2-fold reduction in mean bed shear stress as a result of reductions in water slope upstream of dams.

We estimated a mean annual bedload capacity of $4700 \mathrm{~m}^{3} /$ year for the Rhône River based on an average over the 17 reaches. However, this value varies strongly along the river (from 2500 to $16,300 \mathrm{~m}^{3} /$ year). As shown in Fig. 6, sudden drops in bedload transport capacities occur repeatedly coinciding with reductions in water surface slope upstream of each dam. In order to characterise the behaviour of a typical reach on the Rhône River and to determine a baseline for assessing intra-reach variability, we averaged transport estimates over all the reaches (Fig. 7A). We accounted for variable 
Table 2

Reach-by-reach summary of the main results of the 1D hydrosedimentary model accomplished for the Rhône river in this paper

\begin{tabular}{|c|c|c|c|c|c|c|c|c|c|c|c|c|c|c|c|}
\hline \multirow[t]{2}{*}{ Reach } & \multicolumn{3}{|c|}{ Peak flowing (\%) } & \multicolumn{3}{|c|}{$\begin{array}{l}\text { Ratio present-day/pre-managed } \\
\text { water slope at reservoirs }(\% \circ)\end{array}$} & \multicolumn{3}{|c|}{ Flow competence $(\mathrm{mm})$} & \multicolumn{3}{|c|}{ Estimated bedload capacities ( $\mathrm{m}^{3} /$ year) } & \multicolumn{3}{|c|}{ Number of days bedload transport $>100 \mathrm{~m}^{3} /$ day } \\
\hline & $\begin{array}{l}\text { 2-year } \\
\text { flood }\end{array}$ & $\begin{array}{l}10 \text {-year } \\
\text { flood }\end{array}$ & $\begin{array}{l}50 \text {-year } \\
\text { flood }\end{array}$ & $\begin{array}{l}\text { 2-year } \\
\text { flood }\end{array}$ & $\begin{array}{l}\text { 10-year } \\
\text { flood }\end{array}$ & $\begin{array}{l}50 \text {-year } \\
\text { flood }\end{array}$ & $\begin{array}{l}\text { 2-year } \\
\text { flood }\end{array}$ & $\begin{array}{l}5 \text {-year } \\
\text { flood }\end{array}$ & $\begin{array}{l}10 \text {-year } \\
\text { flood }\end{array}$ & $\begin{array}{l}\text { Bypassed } \\
\text { channel }\end{array}$ & $\begin{array}{l}\text { Non- } \\
\text { regulated } \\
\text { channel }\end{array}$ & $\begin{array}{l}\text { Accros } \\
\text { reservoir }\end{array}$ & $\begin{array}{l}\text { Bypassed ch. } \\
\text { (present-day) }\end{array}$ & $\begin{array}{l}\text { Bypassed ch. } \\
\text { (unimpeded) }\end{array}$ & $\begin{array}{l}\text { Non- } \\
\text { regulated } \\
\text { ch. }\end{array}$ \\
\hline Motz/Lavours & 40 & 55 & 60 & 6 & 13 & 63 & 8 & 8 & 8 & 260 & 1420 & 0 & 0 & 0 & 2 \\
\hline Lavours/Champagneux & 40 & 55 & 60 & 3 & 3 & 48 & $<1$ & $<1$ & $<1$ & 580 & 2160 & 910 & 0 & 0 & 1 \\
\hline Champagneux/Villebois & 41 & 56 & 61 & 1 & 1 & 100 & $<1$ & $<1$ & $<1$ & 50 & 650 & 0 & 0 & 0 & 0 \\
\hline Villebois/Jons & 48 & 62 & 67 & 94 & 87 & 86 & 15 & 15 & 15 & 200 & 14,700 & 1040 & 0 & 11 & 23 \\
\hline Jons/Lyon & 71 & 79 & 82 & 23 & 29 & 23 & 49 & 58 & 62 & 14,300 & 5270 & 510 & 30 & 219 & 10 \\
\hline Pierre Bénite/Vaugris & 57 & 68 & 73 & 50 & 77 & 44 & 33 & 33 & 43 & 3430 & 6960 & 280 & 8 & 73 & 15 \\
\hline $\begin{array}{l}\text { Vaugris/St. Pierre de } \\
\text { Boeuf }\end{array}$ & - & - & - & 45 & 49 & 57 & 13 & 15 & 16 & - & 6020 & 680 & - & - & 14 \\
\hline St. Pierre de Bœuf/Arras & 50 & 63 & 69 & 49 & 63 & 88 & 25 & 30 & 34 & 3510 & 7320 & 820 & 8 & 110 & 16 \\
\hline Arras/La Roche de Glun & 50 & 63 & 69 & 36 & 53 & 66 & 22 & 33 & 39 & 1800 & 6150 & 120 & 3 & 55 & 13 \\
\hline $\begin{array}{l}\text { La Roch de Glun/ } \\
\text { Charmes }\end{array}$ & 38 & 54 & 62 & 40 & 68 & 100 & 25 & 46 & 52 & 2130 & 19,430 & 800 & 4 & 91 & 18 \\
\hline Charmes/Pouzin & 43 & 60 & 68 & 50 & 85 & 100 & 26 & 49 & 58 & 3050 & 12,390 & 2610 & 8 & 127 & 25 \\
\hline Pouzin/Rochemaure & 46 & 62 & 69 & 24 & 42 & 55 & 40 & 60 & 59 & 12,000 & 3470 & 580 & 20 & 219 & 6 \\
\hline Rochemaure/Donzère & 53 & 67 & 73 & 32 & 60 & 78 & 60 & 74 & 80 & 10,100 & 20,600 & 780 & 17 & 182 & 30 \\
\hline Donzère/Caderousse & 50 & 64 & 71 & 24 & 35 & 50 & 53 & 60 & 63 & 16,900 & 3900 & 315 & 32 & 220 & 8 \\
\hline Caderousse/Sauveterre & 48 & 64 & 71 & 37 & 60 & 79 & 23 & 36 & 43 & 1480 & 8110 & 370 & 3 & 29 & 7 \\
\hline Sauveterre/Vallabrègues & 18 & 12 & 10 & 30 & 42 & 47 & 8.4 & 8.9 & 10 & 900 & 1710 & 320 & 0 & ? & 2 \\
\hline Vallabrègues/Diffluence & 57 & 70 & 76 & - & - & - & 30 & 37 & 40 & 1240 & 18,390 & - & 2 & 18 & 40 \\
\hline
\end{tabular}




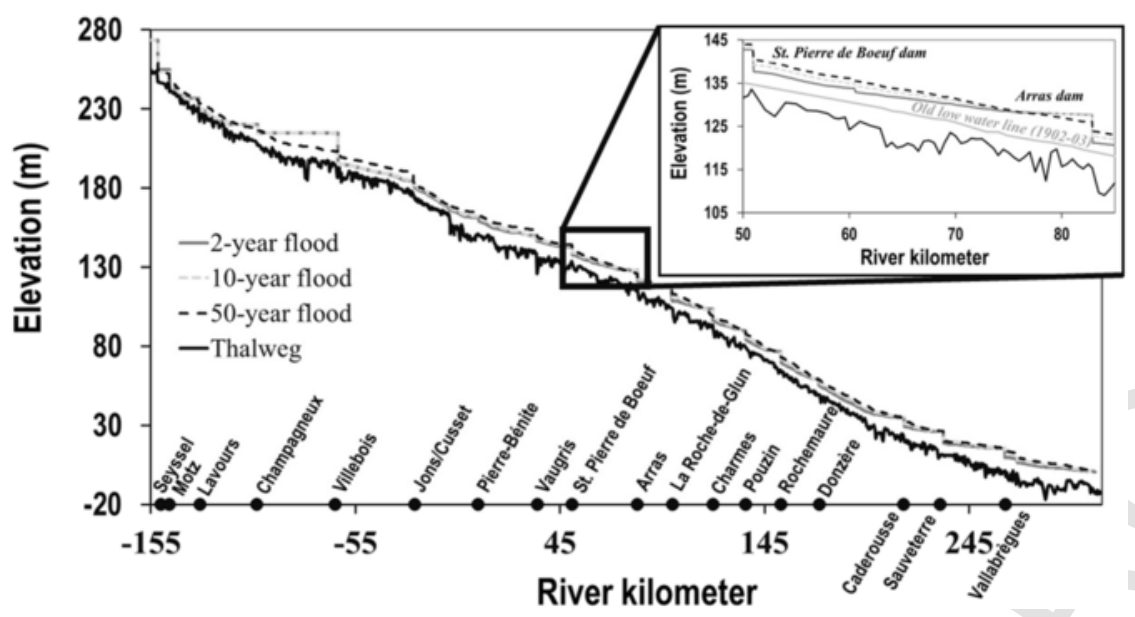

Fig. 4. Water surface elevations along the Rhône River for a range of discharges with a close-up of the St. Pierre de Boeuf/Arras reach (inset).

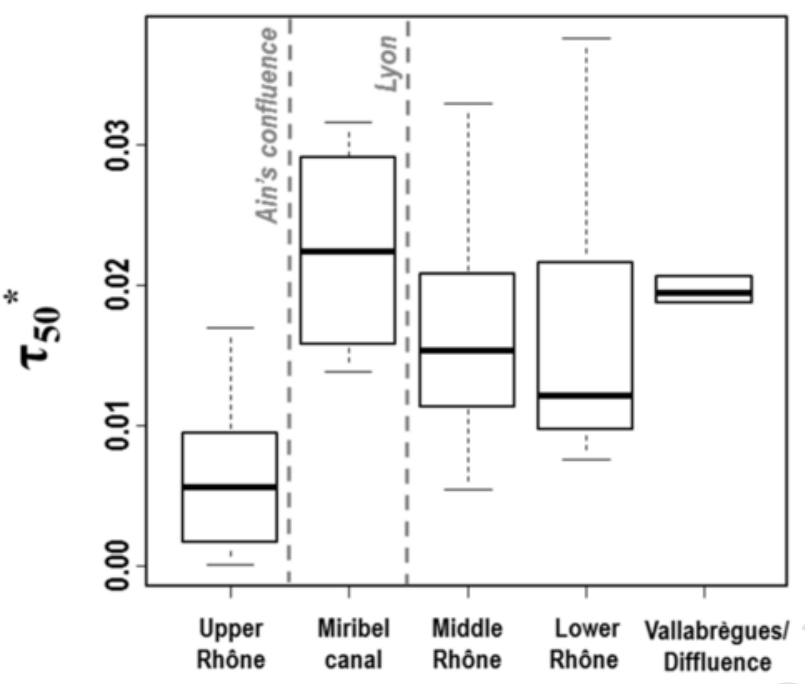

Fig. 5. Shields' parameter values for a 2-year discharge along the Rhône's main channel.

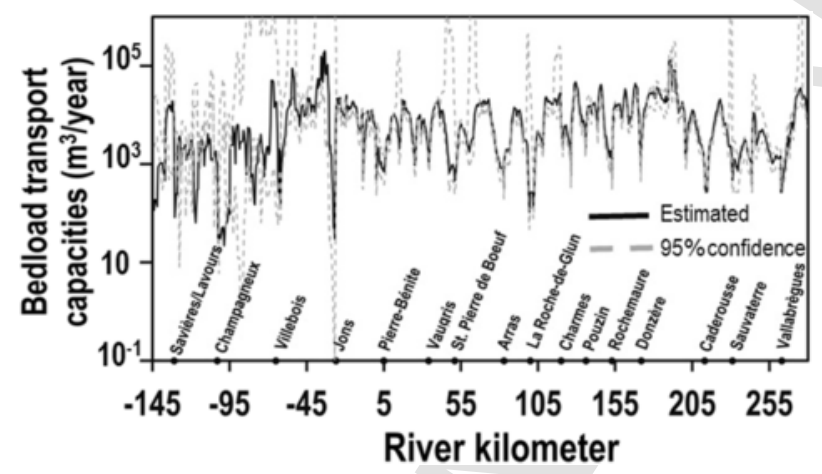

Fig. 6. Estimates of average annual bedload transport capacities along the Rhône river. Gray lines represent the uncertainty intervals based on errors in grain size.

reach lengths in our intra-reach analyses by normalising distances from the upstream dam and from the restitution by the length of the respective subreach: we designated the restitution as 0 and as such the normalised subreach distances are negative upstream and positive downstream. The result shows that a typical reach is characterised by
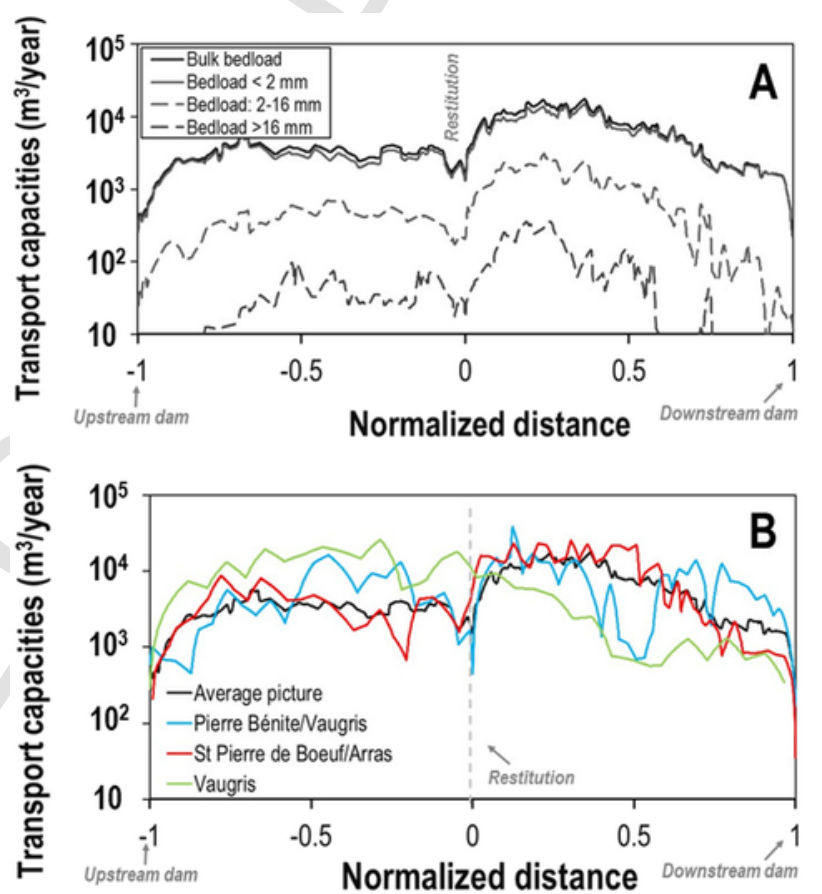

Fig. 7. A) Bedload transport capacities averaged, on a reach-by-reach basis, for the entire Rhône river. $B$ ) In this plot we compare the intra-reach trends in bedload transport capacities for an 'averaged reach' (panel A), with those trends observed in some individual reaches.

low annual bedload transport capacity in the bypassed subreach immediately downstream of the dam. Transport capacity gradually increases downstream and continues to increase downstream of the confluence. Then, it decreases towards the downstream dam.

We used our estimates of the Shields parameter (Fig. 5) to determine potentially mobile grain sizes during floods (Fig. 8A). The results show that, even for a 10 -year-return-period flow, potentially mobilizable sediments along the Rhône River are finer than the median grain size found in the riverbed. These results were confirmed by estimates of the GSD of the transported bedload based on the GTM model showing it to be much finer than the GSD of the bed surface (Fig. 9). Our results suggest that, with the exception of the Villebois/Jons reach just downstream of the confluence with the Ain River, overall bed sediment mobility is very low across the majority 

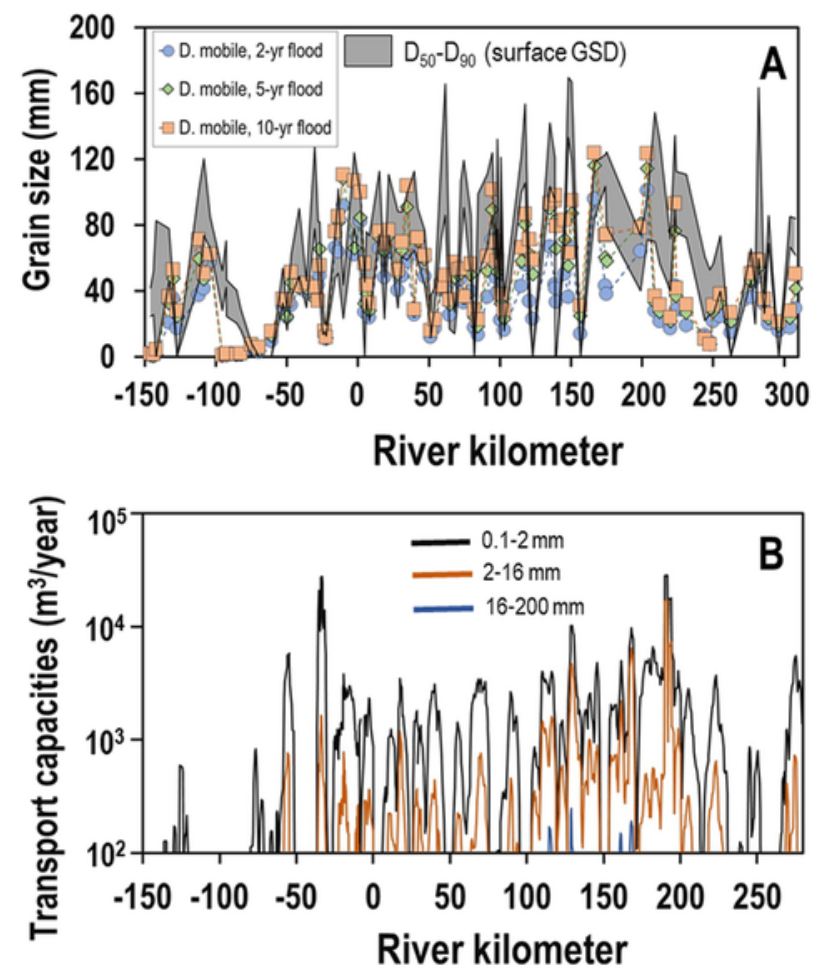

Fig. 8. A) Estimates of flow competence along the Rhône for different discharges compared to grain sizes measured in the bed. B) Fractional bedload transport capacities estimated for the Rhône based on the results of the GTM model (Recking, 2016).

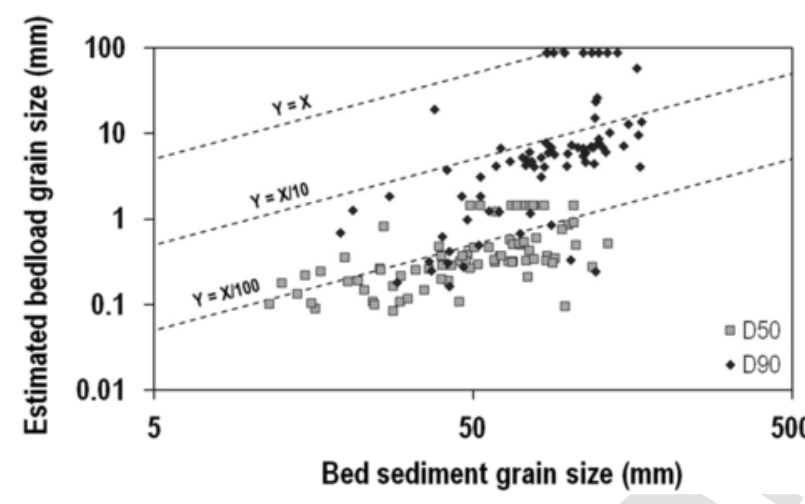

Fig. 9. Comparison of GSD of the bedload estimated from the GTM model (Recking, 2016) and measured bed sediment GSD.

of the present-day Rhône River. In addition, they point towards a condition of only partial mobility; a fully mobile bed is most likely a rare phenomenon in the present-day Rhône.

According to the results of the GTM model, the fine fraction $(0.1<d<2 \mathrm{~mm})$ represents, on average, $89 \%$ of the bedload transported by the Rhône River. This signifies that the Rhône River transports $4200 \mathrm{~m}^{3}$ of fines annually compared to $500 \mathrm{~m}^{3} /$ year of coarse sediments, a result consistent with observations made near the confluence with the Isère River (Camenen et al., this issue; Dépret et al., this issue). The model also showed that drops in transport capacities upstream of dams are more pronounced for coarser sediments than for fines. Indeed, bedload transport of particles $>16 \mathrm{~mm}$ is lacking downstream and upstream of dams (Fig. 8B), likely reflecting armouring effects downstream of dams and backwater effects upstream of dams respectively. In addition, coarser sediments $(>64 \mathrm{~mm})$ are poorly represented in the bedload and their transport seems to be only very local.

\subsection{Effects of (human induced) changes in flow regime and sediment supply on bedload transport capacities}

The analyses presented in the previous section underscore the effects of flow regulation associated with hydropower dams on present-day hydraulics along the Rhône and the consequences for sediment transport. Based on simulations for an unimpeded flow regime using the 1D hydraulic model MAGE, we estimated bedload transport capacities to be, on average, 20 to 25 times higher in the bypassed channels prior to regulation (Fig. 10A). Additionally, based on a comparison of flow duration curves for an unimpeded versus a regulated flow regime, we deduced that these reductions in bedload transport capacities are more likely the result of important decreases in mean flow duration rather than reduced peak flows at larger floods, as evidenced by the more significant difference between the flow duration curves at lower flows (Fig. 11). Furthermore, an estimate of the effects of backwater due to dams (Eqs. (14) and (15)) on bedload transport capacities points towards an average 15 -fold reduction in the Total Rhône during high floods (2-year to 10-year flows).

A comparison of bedload transport computations based on the GSD of samples collected from the surface of gravel bars resulted in an estimate of capacities that were 2 to 3 times higher than those
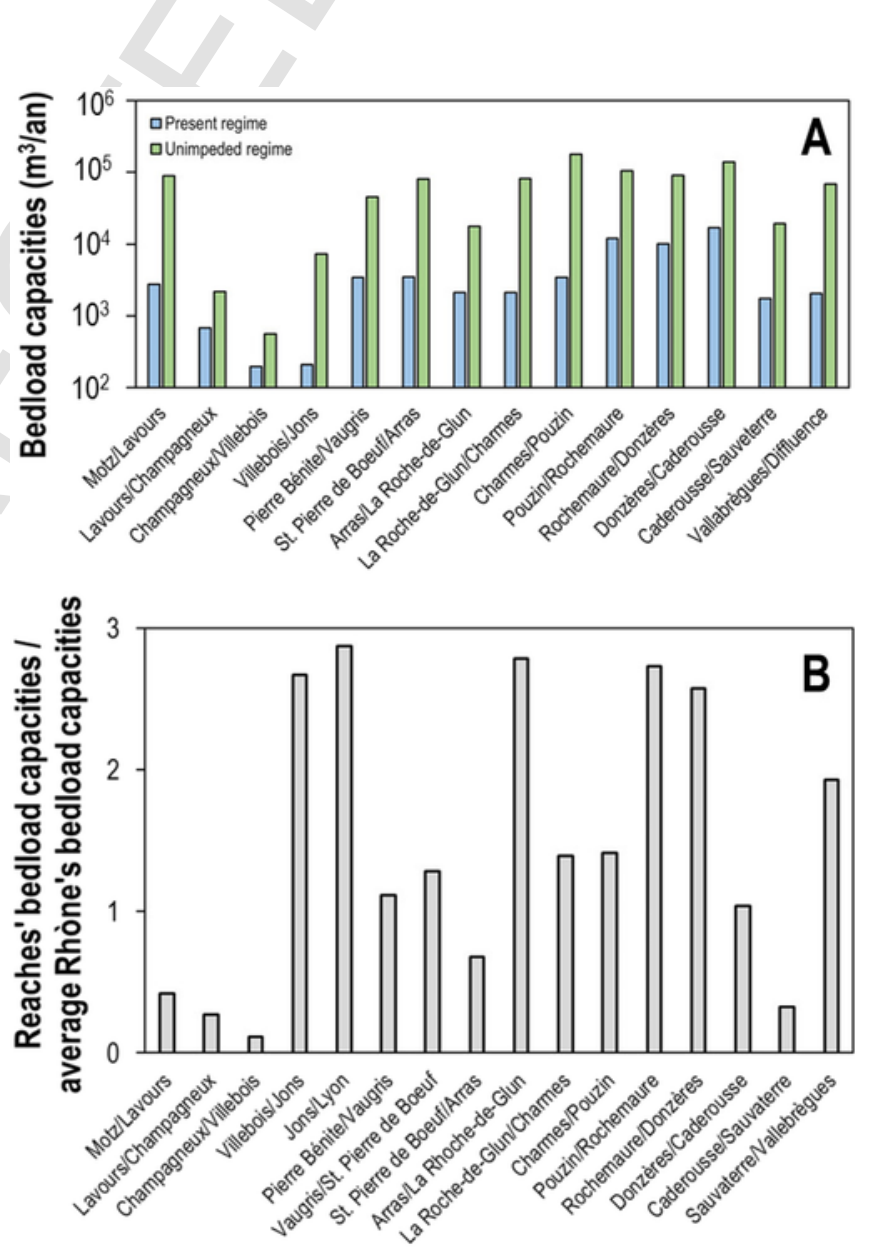

Fig. 10. A) Average annual bedload transport capacities on a reach-by-reach basis estimated for present-day flow conditions and an unimpeded flow regime, and B) ratio of average mean annual bedload capacity per reach to average mean annual bedload capacity for the Rhône. 


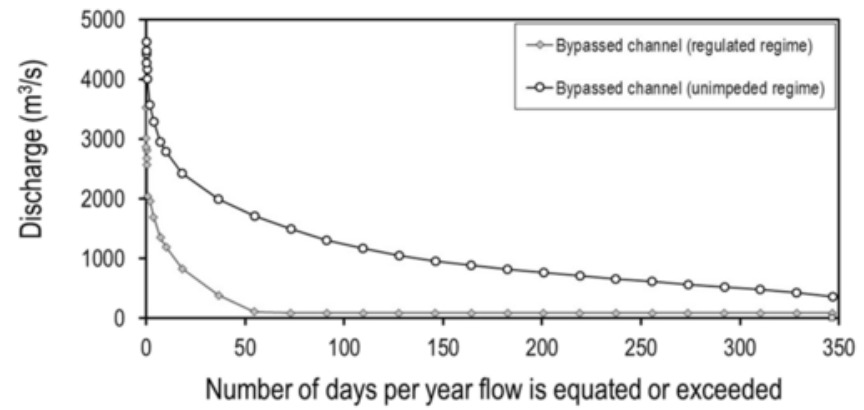

Fig. 11. Flow duration curves in the bypassed subreach of the Péage de Roussillon/Arras reach for an unimpeded and regulated flow regime.

based on samples collected from the channel. Differences were even more significant, approximately 10 times higher, when computations were based on the GSD from the subsurface of bars. Based on these results, we estimated the bedload supply ratio $R_{q s a}$ (Eq. (16)) and assessed how it varies with estimates of armour ratio $\left(D^{*}\right)$ along the channel (Fig. 12). The observed decaying trend is comparable to the one observed for flume experiments by Dietrich et al. (1989) and Venditti et al. (2017), and describes how surface grain size in the Rhône River could have adjusted to available sediment supplies. Coupling this plot with available grain size data (Parrot, 2015) provides a way to determine if a reach underwent small or large decreases in sediment supply. According to the results plotted in Fig. 12, decreases in sediment supply were more important in the reaches downstream of Lyon versus upstream: approximately $25-35 \%$ of the pre-managed sediment supply versus approximately $40-75 \%$ respectively. Supply limitations appear to be less important into the Jons/Lyon reach (Miribel canal), a result coherent with the important sediment supply from the Ain river and confirmed by measurements of active transport in ongoing RFID surveys (Dépret et al., 2017a, 2017b).

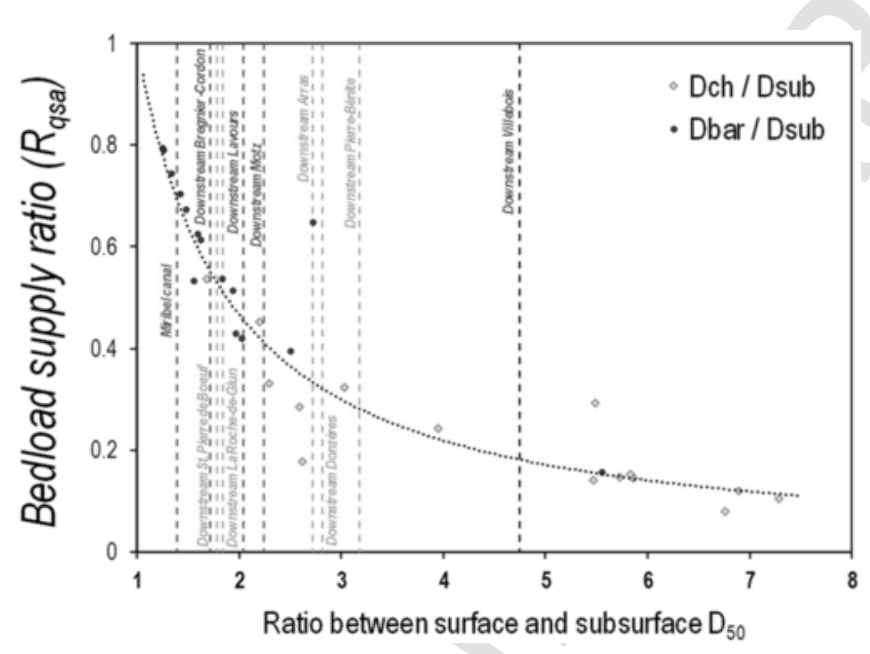

Fig. 12. Bedload supply ratio $R_{q s a}$ (Dietrich et al., 1991) versus all measured armour ratios. Dark circles and light gray diamonds represent measured upstream and downstream of Lyon respectively. $\mathrm{D}_{\text {ch }}, \mathrm{D}_{\text {bar, }}$ and $\mathrm{D}_{\text {sub }}$ are the GSD for the channel, surface of gravel bars and subsurface of gravel bars respectively.

\section{Discussion}

\subsection{Effects of channel embankment versus dams on bed texture, transport capacity, and morphological evolution}

The results of the analyses presented in this study highlighted that the present-day Rhône River is characterised by low flow competence, as evidenced by Shields values that are well below the critical Shields parameter for the onset of motion and by markedly low transport capacities for coarser sediments. Bedload transport capacities along the river are highly variable, with strong reductions immediately downstream and upstream of dams due to armouring and backwater effects respectively. The combination of an estimated 20-25-fold reduction in transport capacities in bypassed subreaches associated with flow diversions, a 15-fold reduction in the unregulated Total Rhône due to backwaters, and up to a 10 -fold reduction due to armouring resulting from vertical incision and sediment deficits, points towards a decrease in transport rates of up to 25 to 35 times compared with pre-management rates (based on an approximation of the total length of river over which different reductions occurred respectively). Based on our estimate of an average annual bedload transport capacity of $4700 \mathrm{~m}^{3} /$ year, this implies a reduction in transport capacities on the order of $47,000 \mathrm{~m}^{3} /$ year due to changes in grain size followed by a reduction of approximately 70,000 to $118,000 \mathrm{~m}^{3} /$ year due to flow regulation (i.e., dams). This result suggests that hydraulic perturbations linked to dams (flow regulation, backwaters) had an impact 2-3 times more important on bedload transport capacities than changes in grain size brought about by incision and sediment deficits (river embankments, lack of coarse sediment transfers across reservoirs, sediment trapping at tributary confluences, and gravel mining).

The bedload supply ratio $\left(R_{q s a} ;\right.$ Eq. $\left.(16)\right)$, as defined by Dietrich et al. (1989) and Venditti et al. (2017), is an indicator of the balance between sediment supply and transport capacity, and subsequent textural adjustments: a $R_{q s a}$ value near one would indicate an equilibrium between transport capacity and sediment supply and an unarmoured or weakly armoured surface, while a $R_{q s a}$ ratio $<1$ would indicate surface armouring in response to a sediment deficit (Venditti et al., 2017). A plot of our estimates of how $R_{q s a}$ evolved with changes in GSD versus present-day armour ratios measured along different reaches of the Rhône (Fig. 12) provides insight into how bedload supply, channel morphology, and surface texture coevolved in the Rhône River in response to different phases of human development. The results suggest that sediment deficits and subsequent armouring were more pronounced downstream of Lyon versus upstream. Considering that the Rhône upstream of Lyon did not undergo systematic channel embankment and preliminary associated channel adjustment (Parrot, 2015), we can attribute reductions in transport capacities and changes in the $R_{q s a}$ solely to the impacts of dams (we assume reductions in supply from tributaries to be uniform across the basin). The fact that reductions in $R_{q s a}$ and armour ratios were lower upstream of Lyon versus downstream, leads us to conclude that bed coarsening was foremost a response to channel embankments. Pre-dam armouring linked to channel narrowing and embankments has been suggested in other studies, e.g. Frings et al. (2009) on the Waal river and Arnaud et al. (2015) on the Rhine. However, the analyses we presented here do not allow us to distinguish between coarsening linked to river embankment and armouring related to sediment deficits. More detailed inspection will likely prove that our hypothesis about the overall response was more nuanced amongst individual reaches. 
Taking $R_{q s a}$ as representing the ratio between bedload rates or yields (numerator in Eq. (16)), i.e., actual volumes of bedload being transferred along the channel, and bedload capacity (denominator in Eq. (16)), i.e., the maximum ability of the channel to mobilize available bed sediment, we propose a conceptual scheme illustrating the trajectories of $R_{\text {qsa }}$ through time along the main stem of the Rhône River (Fig. 13). River embankment led to channel narrowing which in turn enhanced bed shear stresses, prevent bedload supply coming from bank erosion and concentrated bedload transport into a narrower band of main channel. Insofar as this increase in transport capacity was not compensated for by an increase in sediment inputs coming from upstream, channel embankment resulted in bed incision and surface armouring. As a result, $R_{q s a}$ likely decreased initially and stabilized once the bed surface coarsened.

Hydropower dams likely had contrasting effects on different reaches. On one hand, sediment deficits caused by the lack of coarse sediment transfers across reservoirs as well as gravel extractions likely enhanced incision and armour development already underway. Meanwhile, reduced peak flows and flow durations mitigated bed scouring from sediment-free flows into the bypassed channels and promoted channel stability. Providing that enough sediment stores were available in the bypassed channel at the time of dam construction, reduced flows may have even led to local aggradation. These different effects of hydropower dams (decreased yields and decreased capacities) likely resulted in different morphological and textural responses, and thus different $R_{q s a}$ trajectories, depending on which effect was dominant. This variable response is supported by heterogeneity in vertical evolution amongst reaches following dam construction (Parrot, 2015).

\subsection{Natural and anthropogenic factors influencing variability in transport capacities amongst reaches}

When we examine how average transport capacity in each reach compares to the average transport capacity of the whole system, we see considerable variability amongst reaches (Fig. 10B). We attribute this variability to a wide range of anthropogenic and natural factors that have influenced the evolution of individual reaches and continue to act on them today. One obvious explanation for deviations from the average is differences in dam configurations and flow regulation (Table 2). For example, while many reaches exhibit an increase in bedload transport capacity due to the sudden increase in flow discharge downstream of the confluence (e.g. Motz/Lavours, Pierre Bénite/Vaugris), the Vaugris/St.Pierre de Boeuf reach does not exhibit this increase downstream due to the lack of a diversion canal

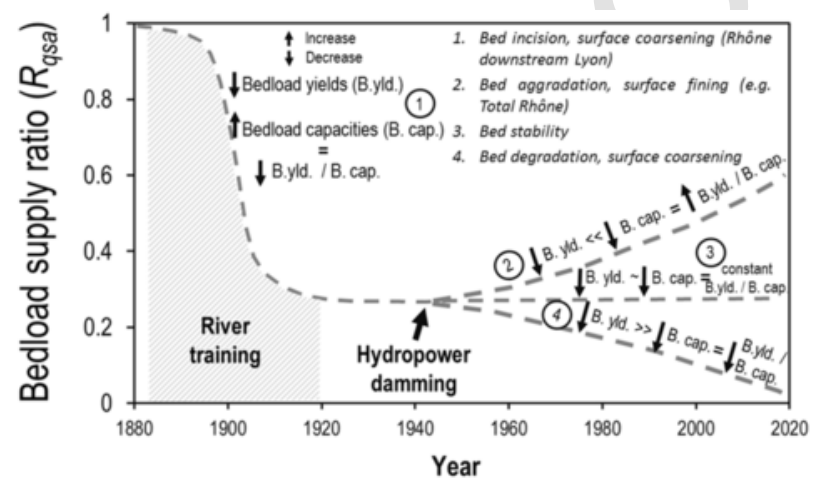

Fig. 13. Conceptual scheme of the temporal trajectory in the ratio between bedload yields and bedload capacities along the main channel of the Rhone and how it relates to vertical bed evolution.
(Vaugris in Fig. 7B). Some of the variability can also be explained by differences in how flow regulation impacts peak discharges (described previously). Yet another source of variability in transport capacities associated with flow regulation may be the extent of backwater behind dams, which naturally has a strong effect on the energy slope of regular flows. In reaches upstream of the confluence with the Ain River, backwater propagates into the bypassed subreach. Consequently, average annual bedload exports from the bypassed channel to the Total Rhône are almost negligible. Around the confluence with the Isère River, the La Roche-de-Glun/Charmes and Charmes/Pouzin reaches are characterised by large differences in estimated bedload capacities between the unimpeded and regulated flow regimes. We attribute this not only to the backwater zone extending into the bypassed subreach, but also to the fact that most of the discharge coming from the Isère River is diverted through the diversion canal (Camenen et al., this issue). Heterogeneity within the drainage basin provides another explanation for why reaches exhibit different transport capacities. For example, low annual transport capacities between river kilometers -103 and -85 can be attributed to naturally occurring lower valley slopes along this reach (0.0003 compared to an average slope of 0.0006; EGR, 2000). Finally, our estimates of transport capacities show an important increase in the Jons/Lyon reach (Miribel canal). Its position downstream of the Ain River, suggests that tributaries with high sediment yields - sediments coming from the Ain are not quarried at the confluence because it is not located in a navigation reach - potentially play an important role in maintaining bed mobility at the reach scale (EGR, 2000). The effects of inputs from tributaries on partially mitigating supply limitations due to dams was highlighted in a study by Batalla et al. (2014) on the Ebro river. Our results show higher bedload transport capacities around the confluences of two other major tributaries: the Drôme and Ardèche Rivers. However, given that the only sediment likely coming from either tributary is sand - major coarse sediment trapping operations are carried out at mouth of the Drôme, and the lower reach of the Ardèche river has been heavily mined (EGR, 2000), we attribute these increases to the increase in flow discharge at the tributary confluences rather than sediment supply.

\subsection{Effects of hydraulic discontinuity on sediment dynamics and implications for management}

Hydraulic fragmentation resulting from the dam series is the most significant modulator of bedload transport in the present-day Rhône River, and dams for hydropower are clearly linked to the main nodes of bedload discontinuity along the river corridor. As other studies have shown (EGR, 2000; Guertault et al., 2018; Camenen, 2017; Camenen et al., this issue), while some sediment is transferred across dams during flushing flows and at high discharges, it is sporadic and mostly limited to the fine fraction of the bedload. These observations are supported by the results of the GTM model presented here.

Consequently, rather than a river continuum, the present-day Rhône functions as 17 separate and independent systems varying in length between 14 and $42 \mathrm{~km}$, each bound between an upstream and downstream dam. River fragmentation halts the transfer of coarse sediment between subsequent reaches, and bedload dynamics within individual reaches consist of a slow transfer of coarse sediment from the bypassed channel to the downstream where it is stored, with occasional replenishment of sand in response to high discharges and flushing flows.

This general scheme resembles the inter-dam sequence described by Skalak et al. (2013) for the Upper Missouri River, which led them to propose a conceptual model of how dam interactions affect river 
geomorphology. Their model presents a morphological sequence with five main river zones from upstream to downstream as follows: (i) a dam proximal zone morphologically controlled by sediment-free water leaving the upstream dam, (ii) an attenuating reach progressively less influenced by the upstream dam, (iii) a river-interaction reach in which the influence of the backwater begins, (iv) a reservoir reach controlled mostly by water impoundment in the reservoir, and, (v) the reservoir itself controlled by the downstream dam. On the Rhône River, this sequence is more complicated because the reach equivalent to the river-interaction reach above is not only affected by the balance between the downstream extent of sediment deficits (i.e., 'hungry water', Kondolf, 1997) and backwater effects, but also by the abrupt increase in discharge at the restitution. Moreover, Skalak et al. (2013) pointed out how the interaction between dams increased in significance when dam spacing was $<100 \mathrm{~km}$. This is because when the length of the inter-dam sequence is longer, there is more opportunity for sediment restocking by bank erosion or tributary inputs, and thus potential for the influence of the upstream dam to become attenuated. In the Rhône River, the length of inter-dam reaches is between 15 and $40 \mathrm{~km}$. Therefore, the downstream effects of the upstream dam always overlap with the influence of the downstream one. Furthermore, sediment restocking along the Rhône is impeded by embankments and reductions in tributary inputs.

Our results point towards bedload transport capacities that are one order of magnitude higher based on subsurface GSD versus surface GSD. This increase may reflect a difference in the river's capacity to mobilize its bed versus its capacity to transport external inputs of sediment. In other words, the Rhône may be capable of transporting allogenic sources of sediment (which on the Rhône are extremely limited due to dams on tributaries, gravel mining, and dredging at tributary mouths), while the bed remains stable. This difference resembles the distinction between travelling bedload and structured bed load described for step-pool channels by Yu et al. (2009), Piton et al. (2016), Piton and Recking (2017) and Vázquez-Tarrío et al. (2018). Structured bed load is defined by the bed surface sediment controlling channel roughness and influencing flow resistance, while travelling bedload refers to supply-limited mobile sediments introduced sporadically into the channel. The distinction between travelling and structured bedload is an important consideration in restoration plans involving sediment replenishment and/or gravel augmentation, as it could lead to material introduced being efficiently transported during floods but with minimal impact on bed morphology and breakup of the armour layer.

Finally, for gravel augmentation to have a significant impact on restoring morphological functioning, it must be considered within the context of longitudinal discontinuities shown in this study and in the one by Dépret et al. (this issue). As both studies have shown, very little sediment is transferred across reservoirs upstream of dams and much of the sediments that do get passed are composed of sand and fine gravels (Camenen et al., this issue). In this context, gravel-augmentation could have a potentially negative impact on the channel. Results of this study suggest that augmentation should be done at the upstream part of long reaches in order to benefit from the maximum possible length as well as time to propagate downstream. Based on studies by Petit et al. (1996) and Bravard (2010), particles moved as bedload at a rate of approximately $100 \mathrm{~m} /$ year in the natural Rhône. In addition, carrying out augmentation operations in parallel with measures promoting widening and lateral connectivity in the bypassed subreaches will help ensure sediments have a morphological impact on the reach and are not only transferred as travelling bedload as in the case of the Rhine River (Arnaud et al., 2017).

\section{Conclusions}

\section{- Present-day bedload transport capacities}

- We estimated present-day section-averaged bed shear stresses, Shields values and flow competence over a range of discharges along the Rhône River based on flow parameters from 1D hydraulic modelling coupled with available grain size data.

- Our flow analyses highlight that the Rhône River is heavily conditioned by hydraulics set up by diversion dams that decrease the frequency of competent flows reaching the bypassed subreaches and create backwater zones.

- Mean annual bedload capacity varies significantly along the channel due to variability in backwater lengths and discharge reductions due to dams, as well as hydrological variability in the basin (slope, tributaries inputs).

- Bed sediment mobility is very low along most of the Rhône River: average Shields parameters for a 2-year flow remain below its critical value for inception of transport and potentially mobile sediments are finer than the median grain size in the riverbed even for a $10-\mathrm{yr}$ flow.

- Effects of human-induced changes in bedload transport capacities

- Estimates based on an unimpeded flow regime points towards a 20-25-fold reduction in transport capacities associated with flow diversions and a 15-fold reduction in the due to backwaters.

- Estimates based on grain size distributions measured from bars point towards a 10-fold reduction due to armouring resulting from vertical incision and sediment deficits.

- Based on an analysis of the ratio of sediment yields to transport capacities compared to measured armour ratios, we conclude that channel embankments were the main cause of bed coarsening.

- We propose a conceptual scheme illustrating how the bedload supply ratio changed through time and how it relates to vertical bed evolution: decreasing ratios in response to channel embankments lead to incision and armouring while the net effect of dams resulted in a heterogeneous response amongst reaches with some remaining stable while others aggraded or degraded.

- Bedload sediment discontinuity related to dams

- A typical inter-dam reach is characterised by low annual bedload transport capacity at the upstream of the bypass subreach immediately downstream of the dam and drops off in the Total Rhône subreach within the backwater of the downstream dam.

- Based on our results using the Generalized Threshold Model (GTM), we estimate that the Rhône River transports mostly sand particles and very little coarse sediment gets transported across reservoirs upstream of dams.

- The short lengths of inter-dam reaches on the Rhône (15-40 km) indicate that the downstream effects of the upstream dam always overlap with the influence of the downstream dam. On the Rhône River, hydro-sedimentary dynamics are thus the result of a complex interaction between reduced flows, sediment deficits, and armouring upstream, followed by increased discharge at the restitution and a backwater effect at the downstream.

- In light of the low rates of sediment transfer to the downstream part of the river, we demonstrated here that gravel augmentation (either through re-injections or through increased lateral erosion) may be an effective restoration strategy on the Rhône. However, our results highlight the need to consider flow competence and transfer times and rates on a reach-by-reach basis to ensure its success. 


\section{Uncited references}

Cortier and Couvert, 2001

Hupp et al., 2009

Michelot, 1989

Nilsson et al., 2005

Peiry and Bravard, 1989

Pichard, 1995

Stroffek et al., 1996

Uribelarrea et al., 2003

\section{Acknowledgments}

This study was conducted within the Rhône Sediment Observatory (OSR), a multi-partner research program funded through the Plan Rhône by the European Regional Development Fund (ERDF), Agence de l'eau RMC, CNR, EDF and three regional councils (Auvergne-Rhône-Alpes, PACA and Occitanie). This work was cofunded by the Labex DRIIHM, French programme 'Investissements d'Avenir' (ANR-11-LABX-0010) which is managed by the ANR. At the time of preparation of this manuscript, Vazquez-Tarrio benefitted from grant ACB17-44 cofunded by the Clarin-FICYT (Principality of Asturias) and the Marie Curie programme, as well as support from the project RIVERCHANGES-CGL2015-68824-R (MINECO/FEDER, UE). We thank Thomas Depret for fruitful exchanges that helped improve the quality of this work.

\section{Notations}

GSD grain size distribution

$D_{i} \quad i$-th percentile of the GSD

$D_{m o b} \quad$ potential mobile grain size

$K_{s} \quad$ Strickler coefficient

$p \quad$ bed material porosity

$\rho \quad$ water density

$\rho_{s} \quad$ sediment density

$S_{f} \quad$ energy slope

$R$

$U$

$\tau$

$\tau^{*}$

$\tau_{\mathrm{av}}$

$\tau_{\max }$

$\tau^{*}{ }_{84}$

$\tau^{*}{ }_{m}$

$\theta$

$\tau^{*}{ }_{c 84}$

$q_{s}^{*}$

$q_{s}$

$R_{q s a}$

$\alpha$

$\beta$

$\gamma$

$\gamma_{0}, \gamma_{1}, \gamma_{2}$ $\varphi_{i}$

$\varphi_{0}$

$\sigma_{D}$

$\sigma_{\text {int }}$

Appendix A.

fraction of the ith bed surface percentile that is mobile minimum value of $\varphi i$ representability of grain-size samples standard deviation of grain size errors

\begin{tabular}{|c|c|c|c|c|}
\hline Study reach & Source & $\begin{array}{l}\text { Bed shear } \\
\text { stress }(\mathrm{N} / \\
\left.\mathrm{m}^{2}\right)\end{array}$ & $\begin{array}{l}\mathrm{D}_{50}(\mathrm{~mm}) \\
\text { bedload }\end{array}$ & $\begin{array}{l}\text { Dmax } \\
(\mathrm{mm}) \text { bed- } \\
\text { load }\end{array}$ \\
\hline \multirow[t]{4}{*}{$\begin{array}{l}\text { Pierre Bénite/ } \\
\text { Vaugris }\end{array}$} & $\begin{array}{l}\text { Ramette and } \\
\text { Heuzel (1962) }\end{array}$ & 31.2 & - & 75 \\
\hline & & 26.5 & - & 50.0 \\
\hline & & 26.4 & - & 45.0 \\
\hline & & 22.7 & - & 25.0 \\
\hline \multirow[t]{2}{*}{$\begin{array}{l}\text { Jons/Lyon (Miri- } \\
\text { bel canal) }\end{array}$} & $\begin{array}{l}\text { Poinsart } \\
\text { (1992); Petit et } \\
\text { al. (1996) }\end{array}$ & 18.5 & $13.5-32.3$ & $45.3-98.5$ \\
\hline & & 22.5 & $14.3-31.9$ & $44.5-118.1$ \\
\hline
\end{tabular}

Data used in order to calibrate the GTM model (Recking, 2016) for the Rhône river.

\section{References}

Anderson, E.P., Jenkins, C.N., Heilpern, S., Maldonado-Ocampo, J., Carvajal-Vallejos, F.M., Encalada, A.C., Rivadeneira, J.F., Hidalgo, M., Cañas, C.M., Ortega, H., Salcedo, N., Maldonado, M., Tedesco, P.A., 2018. Fragmentation of Andes-to-Amazon connectivity by hydropower dams. Sci. Adv. 4 (1).

Arnaud, F., Piegay, H., Schmitt, L., Béal, D., 2015. Historical geomorphic analysis (1932-2011) of a by-passed river reach in process-based restoration perspectives: the old Rhine downstream of the Kembs diversion dam (France, Germany). Geomorphology 236, 163-177.

Arnaud, F., Piegay, H., Béal, D., Collery, P., Vaudor, L., Rollet, A.J., 2017. Monitoring gravel augmentation in a large regulated river and implications for process-based restoration. Earth Surf. Process. Landf. 42 (13), 2147-2166.

Batalla, R., Vericat, D., Tena, A., 2014. The fluvial geomorphology of the lower Ebro (2002-2013): bridging gaps between management and research. In: Cuadernos de Investigación Geográfica. 40(1)

Bergillos, R.J., Rodríguez-Delgado, C., Millares, A., Ortega-Sánchez, M., Losada, M.A., 2016. Impact of river regulation on a Mediterranean delta: assessment of managed versus unmanaged scenarios. Water Resour. Res. 52 (7), 5132-5148.

Brandt, S.A., 2000. Classification of geomorphological effects downstream of dams. Catena 40, 375-401.

Bravard, J.P., 2010. Discontinuities in braided patterns: the River Rhône from Geneva to the Camargue delta before river training. Geomorphology 117, 219-233.

Bravard, J.P., Gaydou, P., 2015. Historical development and integrated management of the Rhône River foodplain, from the Alps to the Camargue delta, France. In: Hudson, P.F., Middelkoop, H. (Eds.), Geomorphic Approaches to Integrated Floodplain Management of Lowland Fluvial Systems in North America and Europe. Springer, New York, pp. 289-320.

Brunier, G., Anthony, E.J., Goichot, M., Provansal, M., Dussouillez, P., 2014. Recent morphological changes in the Mekong and Bassac river channels, Mekong delta: the marked impact of river-bed mining and implications for delta destabilisation. Geomorphology 224, 177-191.

Camenen, B., 2017. Effet des barrages sur la continuité sédimentaire. La Houille Blanche 6, 19-24, (in French).

Camenen, B., Larson, M., 2005. A general formula for non-cohesive bed-load sediment transport. Estuar. Coast. Shelf Sci. 63 (1), 249-260.

Camenen, B., Naudet, G., Dramais, G., Le Coz, J., Paquier, A., 2018. Evaluation of the sand dynamics in a complex engineered river system: the Isère-Rhône confluence, France. Sci. Total Environ.(this issue).

Chien, N., 1985. Changes in river regime after the construction of upstream reservoirs. Earth Surf. Process. Landf. 10, 143-159.

Church, M., Hassan, M.A., 2005. Estimating the transport of bed material at low rate in gravel armoured channels. In: Batalla, R.J., Garcia, C. (Eds.), Geomorphological Processes and Human Impacts on River Basins. Publication 299, IAHS, Wallingford, UK, pp. 141-153. 
Cœur, D., 2017. Etude historique des prélèvements de sédiments dans le Rhône. 1954-2010. In: Rapport CNR, (53 pp., in French).

Cortier, B., Couvert, B., 2001. Causes et conséquences du blocage actuel de la dynamique fluviale et du transit sédimentaire du Rhône. La Houille Blanche 8, (in French).

Dade, W.B., Renshaw, C.B., Magilligan, F.J., 2011. Sediment constraints on river response to regulation. Geomorphology 126, 245-251.

Dépret, T., Riquier, J., Piégay, H., 2017. Evolution of abandoned channels: insights on controlling factors in a multi-pressure river system. Geomorphology 294, 99-118.

Dépret, T., Piégay, H., Cassel, M., Noirot, B., Bultingaire, L., Yousefi, S., Michel, K. Dugué, V., Camenen, B., 2017. Mesures et modélisations du fonctionnement hydrosédimentaire du secteur de Miribel-Jonage. In: Rapport de l'Observatoire des Sédiment du Rhône, (16 pp., in French).

Dépret, T., Piégay, H., Dugué, V., Vaudor, L., Noirot, B., Faure, J.-B., Cassel, M., Le Coz, J., Camenen, B., 2018. Is a run-of-river reservoir transparent to bedload transport? Feedbacks for restoring longitudinal sediment connectivity. Sci. Total Environ.(this issue).

Dietrich, W.E., Kirchner, J.W., Ikeda, H., Iseya, F., 1989. Sediment supply and the development of the coarse surface layer in gravel-bedded rivers. Nature 340, 215-217.

Dufour, S., Piégay, H., 2009. From the myth of a lost paradise to targeted river restoration: forget natural references and focus on human benefits. River Res. Appl. 25 (5), 568-581.

Dugué, V., Walter, C., Andriès, E., Launay, M., Le Coz, J., Camenen, B., Faure, J.-B. 2015. Accounting for Hydropower Schemes' Operation Rules in the 1D Hydrodynamic Modeling of the Rhône River From Lake Geneva to the Mediterranean Sea, 36th IAHR 2015 World Congress, The Hague, The Netherlands.

Dugué, V., Le Coz, J., Camenen, B., Faure, J.-B., 2016. Rapport sur le développement le calage et l'amélioration du modèle hydro-sédimentaire 1D du Rhône du Lac Léman à la Mer Méditerranée (OSR 4). In: OSR4 2015-17, Technical Report, (in French).

Duró, G., Crossatto, A., Tassi, P., 2015. Numerical study on river bar response to spatial variations of channel width. Adv. Water Resour. 93.

EGR, 2000. Etude Globale pour une stratégie de réduction des risques dus aux crues du Rhône. In: Technical Repport Edited by SOGREAH.

Faure, J.B., 2009. Résolution des équations de Barré de Saint-Venant 1D en réseaux complexes. In: Technical Report. 190, pp. 9-10, (in French).

Frings, R.M., Berbee, B.M., Erkens, G., Kleinhans, M.G., Gouw, M.J.P., 2009. Human-induced changes in bed shear stress and bed grain size in the River Waal (The Netherlands) during the past 900 years. Earth Surf. Process. Landf. 34 (4), 503-514.

Frings, R.M., Döring, R., Beckhausen, C., Schüttrumpf, H., Vollmer, S., 2014. Fluvial sediment budget of a modern, restrained river: the lower reach of the Rhine in Germany. Catena 122, 90-102.

Frings, R.M., Gehres, N., Prommy, M., Middelkoop, H., Schüttrumpf, H., Vollmer, S., 2014. Today's sediment budget of the Rhône River channel, focusing on the Upper Rhine Graven and Rhenish Massif. Geomorphology 204, 573-587.

Fruguet, J.F., 2003. Changements environnementaux, dérives biologiques et perspectives de restauration du Rhône français: bilan de 200 ans d'influences anthropiques. VertigO 4 (3), 1-17, (in French).

Fruguet, J.F., Dessaix, J., 2002. Biodiversité structurelle et fonctionnelle des peuplements de macro-invertébrés en tant que descripteur de la variabilité hydraulique: exemple de deux parties court-circuitées du Rhône moyen. Rev. Sci. Eau 15 (numéro spécial CILEF), 209-221, (in French).

Gaeuman, D., 2012. Mitigating downstream effects of dams. In: Church, M., Biron, P., Roy, A.G. (Eds.), Gravel-bed Rivers: Processes, Tools, Environments. 563, John Wiley \& Sons, Chichester.

Gölz, E., 1994. Bed degradation-nature, causes, counter measures. Water Sci. Technol. 29 (3), 325-333.

Gomez, B., Naff, R.L., Hubell, D.W., 1989. Temporal variations in bedload transport associated with the migration of bedforms. Earth Surf. Process. Landf. 14 $135-156$.

Graf, W.L., 2005. Geomorphology and American dams: the scientific, social, and economic context. Geomorphology 71, 3-26.

Graf, W.L., 2006. Downstream hydrologic and geomorphic effects of large dams on American rivers. Geomorphology 79, 336-360.

Grant, G.E., 2012. The geomorphic response of gravel-bed rivers to dams: perspectives and prospects. In: Church, M., Biron, P., McRoy, A. (Eds.), Gravel-bed rivers. Processes, tools, environments. John Wiley and Sons, pp. 165-179.

Guertault, L., Camenen, B., Paquier, A., Peteuil, C., 2018. Sediment transport dynamics in an elongated dam reservoir during flushing operations. Earth Surf. Process. Landf. 43, 373-386.

Habersack, H., Piégay, H., 2007. 27 river restoration in the Alps and their surroundings: past experience and future challenges. In: Developments in Earth Surface Processes 11, pp. 703-735.
Hohensinner, S., Jungwirth, M., Muhar, M., Schmutz, S., 2014. Importance of multi-dimensional morphodynamics for habitat evolution: Danube River 1715-2006. Geomorphology 215, 3-19.

, . Geol. Soc. Am. Spec. Pap.

Kondolf, G.M., 1997. Hungry waters: effects of dams and gravel mining on river channels. Environ. Manag. 21 (4), 533-551.

Kondolf, G.M., Gao, Y., Annandale, G.W., Morris, G.L., Jiang, E., Zhang, J., Cao, Y., Carling, P., Fu, K., Guo, Q., Hotchkiss, R., Peteuil, C., Sumi, T., Wang, H., Wang, Z., Wei, Z., Wu, B., Wu, C., Yang, C., 2014. Sustainable sediment management in reservoirs and regulated rivers: experiences from five continents. Earth's Future 2, 256-280.

Kuhnle, R.A., Willis, J.C., 1992. Mean size distribution of bed load on Goodwin Creek. J. Hydraul. Eng. 118, 1443-1446.

Lamouroux, N., Olivier, J.M., Piegay, H., Merigoux, S., Doledec, S., Segura, S., Castella, E., Riquier, J., Parrot, E., Forcellini, M., 2012. Effets de la restauration du Rhône et potentiel - Synthèse par secteurs. In: Action n²4 du Programme 2010 au titre de l'accord cadre. Agence de l'Eau ZABR, (26 pp., in French).

Launay, M., Dugué, V., Faure, J.-B., Coquery, M., Camenen, B., Le Coz, J., 2018. Numerical modelling of the suspended particulate matter dynamics in a regulated river network. Sci. Total Environ.(this issue).

Lisle, T.E., 1995. Particle size variations between bed load and bed material in natural gravel bed channels. Water Resour. Res. 31, 1107-1118.

Lóczy, D., 2007. The Danube: morphology, evolution and environmental issues. In: Gupta, A. (Ed.), Large Rivers: Geomorphology and Management. John Wiley \& Sons, Chichester, pp. 235-260.

Magilligan, F.J., Nislow, K.H., 2005. Changes in hydraulic regime by dams. Geomorphology $71,61-78$.

McLean, D.G., 1985. Sensitivity analysis of bedload equations. In: Proceedings Canadian Society for Civil Engineering, Annual Conference, Saskatoon, 27-31 May. 1B, pp. 1-15.

Meyer Peter, R., Müller, R., 1948. Formulas for bedload transport. In: Proceedings 2nd Meeting. International Association of Hydraulic Research, Stockholm, pp. 39-64.

Michelot, J.L., 1989. Les espaces naturels de la vallée du Rhône, éléments pour une politique de gestion intégrée (Thèse de Doctorat). 3, Université Lyon, (523 pp., in French).

Nicollet, G., Uan, M., 1979. Steady open channel flows in compound channels [Ecoulements permanents à surface libre en lits composés]. La Houille Blanche 1, 21-30.

Nilsson, C., Reidy, C.A., Dynesius, M., Revenga, C., 2005. Fragmentation and flow regulation of the world's large river systems. Science 308 (5720), 405-408.

Ock, G., Sumi, T., Takemon, Y., 2013. Sediment replenishment to downstream reaches below dams: implementation perspectives. Hydrol. Res. Lett. 7 (3), 54-59.

Olivier, J.M., Carrel, G., Lamouroux, N., Dole-Olivier, M.J., Malard, F., Bravard, J.P., Amoros, C., 2009. The Rhône river basin. In: Robinson, C., Uehlinger, U., Tockner, K. (Eds.), Rivers of Europe. Elsevier, San Diego, pp. 247-295.

Parker, G., 2004. 1D Sediment Transport Morphodynamics With Applications to Rivers and Turbidity Currents, (E-book).

Parker, G., Seminara, G., Solari, L., 2003. Bed load at low shields stress on arbitrarily sloping beds: alternative entrainment formulation. Water Resour. Res. 39 (7), 1183

Parrot, E., 2015. Analyse spatio-temporelle de la morphologie du chenal du Rhône du Léman à la Mediterranée (PhD dissertation). Lyon 3 University, (469 pp., in French).

Petit, F., Poinsart, D., Bravard, J.P., 1996. Channel incision, gravel mining and bedload transport in the Rhône river upstream of Lyon, France ("canal de Miribel"). Catena $26(3-4), 209-226$

Petts, G.E., Gurnell, A.M., 2005. Dams and geomorphology: research progress and future directions. Geomorphology 71, 27-47.

Pitlick, J., Cui, Y., Wilcock, P., 2009. Manual for Computing Bed Load Transport Using BAGS. USDA, Forest Service, Rocky Mountain Research Station, Colorado (USA).

Piton, G., Recking, A., 2017. The concept of travelling bedload and its consequences for bedload computation in mountain streams. Earth Surf. Process. Landf.

Piton, G., Vázquez-Tarrío, D., Recking, A., 2016. Can bed-load help to validate hydrology studies in mountainous catchment? The case study of the Roize (Voreppe - FR). In: E3S Web of Conferences. vol. 7, FloodRisk, Lyon, https://doi.org/10. 1051/e3sconf/20160704020, (12 pp.).

Poinsart, D., 1992. Effets des aménagements fluviaux sur les débits liquides et solides. L'exemple du Rhône dans les plaines de Miribel-Jonage et de Donzère-Mondragon. Thèse de Géographie et Aménagement. Université Lyon 3, (501 pp., in French).

Provansal, M., Dufour, S., Sabatier, F., Anthony, E.J., Raccasi, G., Robresco, S., 2014 The geomorphic evolution and sediment balance of the lower Rhône River (southern France) over the last 130 years: hydropower dams versus other control factors. Geomorphology 219, 27-41. 
Ramette, M., Heuzel, M., 1962. Le Rhône à Lyon Etude de l'entraînement des galets à l'aide de traceurs radioactifs, Essai pour l'extension de la formule de Meyer-Peter au domaine du charriage partiel, Houille Blanche. 1962, 389-399, (in French).

Recking, A., 2013. Simple method for calculating reach-averaged bed-load transport. J. Hydraul. Eng. ASCE 139, 70-75.

Recking, A., 2016. A generalized threshold method for computing bed load grain size distribution. Water Resour. Res. 52 (12).

Recking, A., Piton, G., Vázquez-Tarrío, D., Parker, G., 2016. Quantifying the morphological print of bedload transport. Earth Surf. Process. Landf. 41 (6), 809-822.

Schiemer, F., Baumgartner, C., Tockner, K., 1999. Restoration of floodplain rivers: the "Danube restoration project". River Res. Appl. 15, 231-244.

Schmidt, J.C., Wilcock, P.R., 2008. Metrics for assessing the downstream impacts of dams. Water Resour. Res. 44.

Segura, C., Pitlick, J., 2015. Coupling fluvial-hydraulic models to predict gravel transport in spatially variable flows. J. Geophys. Res. Earth Surf. 120.

Siele, M., Blom, A., Frings, R., Viparelli, E., 2017. Causes of Long-term Bed Degradation in Rivers: Setup of Research. 98-99, (Abstract from NCR-Days 2017, Wageningen, Netherlands).

Singer, M.B., 2006. The influence of major dams on hydrology through the drainage network of Sacramento River basin, California. River Res. Appl. 23, 55-72.

Skalak, K.J., Benthem, A.J., Schenk, E.R., Hupp, C.R., Galloway, J.M., Nustad, R.A., Wiche, G.J., 2013. Large dams and alluvial rivers in the Anthropocene: the impacts of the Garrison and Oahe dams on the Upper Missouri River. Anthropocene $2,51-64$.

Stroffek, S., Amoros, C., Zylberblat, M., 1996. La logique de réhabilitation physique appliquée à un grand fleuve: le Rhône. Géocarrefour 71 (4), 287-296, (in French)

Surian, N., 1999. Channel changes due to river regulation: the case of the Piave River, Italy. Earth Surf. Process. Landf. 24 (12), 1135-1151.

Surian, N., Cisotto, A., 2007. Channel adjustments, bedload transport and sediment sources in a gravel-bed river, Brenta River, Italy. Earth Surf. Process. Landf. 32, $1641-1656$.
Surian, N., Rinaldi, M., 2003. Morphological response to river engineering and management in alluvial channels in Italy. Geomorphology 50, 307-326.

Tricart, J., Bravard, J.P., 1991. L'aménagement des trois plus grands fleuves européens: Rhin, Rhône et Danube. Problèmes et méfaits. Ann. Géog. 100 (561-562), 668-713, (in French).

,. Quat. Sci. Rev.

Vázquez-Tarrío, D., Menéndez-Duarte, R., 2015. Assessment of bedload equations using data obtained with tracers in two coarse-bed mountain streams (Narcea River basin, NW Spain). Geomorphology 238, 78-93.

Vázquez-Tarrío, D., Recking, A., Liébault, F., Tal, M., Menéndez-Duarte, R., 2018 Particle transport in gravel-bed rivers: revisiting passive tracer data. Earth Surf. Process. Landf.

Venditti, J., Nelson, P.A., Bradley, R.W., Haught, D., Gitto, A.B., 2017. Bedforms, structures mobile patches and sediment supply in gravel-bedded rivers. In: Tsutsumi, D., Laronne, J.B. (Eds.), Gravel-bed Rivers. Processes and Disasters. Wiley-Blackwell, UK, pp. 439-466.

Vericat, D., Batalla, R.J., 2006. Sediment transport in a large impounded river: the lower Ebro, NE Iberian Peninsula. Geomorphology 79, 72-92.

Vörösmarty, C.J., Meybeck, M., Fekete, B., Sharma, K., Green, P., Syvitski, J.P.M., 2003. Anthropogenic sediment retention: major global impact from registered river impoundments. Glob. Planet. Chang. 39, 169-190.

Wilcock, P.R., Crowe, J.C., 2003. Surface-based transport model for mixed-size sediment. J. Hydraul. Eng. 129 (2), 120-128.

Williams, G.P., Wolman, M.G., 1984. Downstream Effects of Dams on Alluvial Rivers. United States Geological Survey, Professional Paper 1286.

Wong, M., Parker, G., 2006. 2006. Re-analysis and corrections of bedload relation of Meyer-Peter and Müller using their own database. J. Hydraul. Eng. 132 (11), 1159-1168.

Yu, G.A., Wang, Z.Y., Zhang, K., Chang, T., Liu, H., 2009. Effect of incoming sediment on the transport rate of bed load in mountain streams. Int. J. Sediment Res. 24 (3), 260-273. 